\title{
Water Infrastructure Development in Nigeria: Trend, Size, and Purpose
}

\author{
Adegboyega Adeniran ${ }^{1, *}$, Katherine A. Daniell ${ }^{2}$ [D and Jamie Pittock ${ }^{1}$ (i) \\ 1 Fenner School of Environment and Society, The Australian National University, 48 Linnaeus Way, Canberra, \\ ACT 2600, Australia; jamie.pittock@anu.edu.au \\ 2 Fenner School of Environment and Society \& Institute for Water Futures, The Australian National University, \\ 48 Linnaeus Way, Canberra, ACT 2600, Australia; Katherine.Daniell@anu.edu.au \\ * Correspondence: adegboyega.adeniran@anu.edu.au
}

check for

updates

Citation: Adeniran, A.; Daniell, K.A.; Pittock, J. Water Infrastructure Development in Nigeria: Trend, Size, and Purpose. Water 2021, 13, 2416. https://doi.org/10.3390/w13172416

Academic Editor: João Filipe Santos

Received: 27 July 2021

Accepted: 27 August 2021

Published: 2 September 2021

Publisher's Note: MDPI stays neutral with regard to jurisdictional claims in published maps and institutional affiliations.

Copyright: (c) 2021 by the authors. Licensee MDPI, Basel, Switzerland. This article is an open access article distributed under the terms and conditions of the Creative Commons Attribution (CC BY) license (https:/ / creativecommons.org/licenses/by/ $4.0 /)$.

\begin{abstract}
Water infrastructure development is key to attaining sustainable development, especially for water supply, sanitation and health, agricultural development, and energy production. However, sub-Saharan African countries face specific challenges around infrastructure financing, systemic and repeated malfunctioning, and decentralised infrastructure types. Using Nigeria as a case, this article aims to analyse historical water infrastructure development in Nigeria with a specific focus on dams and standpipes. Seven themes are discussed: infrastructure divisions; deprioritising water supply; political infrastructures; infrastructure failure and sustainability; infrastructure classification and typologies; optimal use of water resources and infrastructure; and a commentary on the future of water infrastructure development. The article concludes with policy and research suggestions for policymakers and other relevant stakeholders.
\end{abstract}

Keywords: dams; Nigeria; standpipes; sub-Saharan Africa; water supply infrastructure

\section{Introduction}

There is a global consensus that water infrastructure development is key to attaining the sustainable development goals (SDGs) [1-5]. Specific targets in the SDGs related to water infrastructure include: achieving universal access to electricity and increasing renewable energy, improving number of population with safely managed water, sanitation and hygiene, providing efficient agricultural and flood control systems, and protecting water-related ecosystems [6]. Valuation of water infrastructure is an important step in ensuring that today's hydraulic development is informed by past lessons to shape the future [7]. Nigeria and sub-Saharan Africa more broadly, have specific needs in water supply, sanitation and health, agricultural development, and energy production [8-11]. However, sub-Saharan African countries face critical challenges around infrastructure financing [5,12,13], systemic and repeated malfunctioning [12], and decentralised infrastructure types [13]. The historical dimension to these issues in Nigeria [14,15], and the contributions made by international and multilateral organisations in Nigeria's water infrastructure development through financing, policy and technology further complicates these issues [16,17]. Combining this history with Nigeria's external relations places water infrastructure development within broader water governance and political governance frames.

Nigeria has consistently lagged in meeting her global water security commitments on health, agriculture, potable water supply, and environmental sustainability [18,19]. Although access to water has increased from 51 percent in 1990 to 68 percent in 2016, approximately 54 percent of rural and 78 percent of urban inhabitants currently have access. Demographic increases (rural-urban) continue to strain the sustainability of current progress, and service coverage may decline by the end of the Sustainable Development Goals $[20,21]$. At the local level, Nigeria's population and high fertility rates mean it will be 
the third-most populous country in the world by 2050, after China and India [22]. Nigeria's population increase will also mean more challenges related to water resources development. Only 15 percent of the 3.14 million hectares of potentially irrigable land is irrigated [23,24], yet Nigeria spent approximately US $\$ 22.5$ billion on food imports in 2017 [25].

Accounting for these scenarios requires an evaluation of the current state of water infrastructure development in Nigeria. Thus, this article analyses historical water infrastructure development in Nigeria with a specific focus on dams and standpipes. This study contributes to the historical literature on water infrastructure development and provides practical policy and research ideas for government and non-government stakeholders engaged in water resources and infrastructure development. Specifically, the historical direction of water infrastructure development and the impact of policy and governance choices on spatial and infrastructural equities. Following this introduction, we present the materials and methods in Section 2, then briefly discuss Nigeria's water governance and its position within sub-Saharan Africa in Section 3. Section 4 presents historical and spatial trends in dam ownership and development, dam size, and dam purpose for water resources development. These trends are discussed in Section 5 through seven themes: infrastructure divisions; deprioritising water supply; political infrastructures; infrastructure failure and sustainability; infrastructure classification and typologies; optimal use of water resources and infrastructure; and a commentary on the future of water infrastructure development. The article concludes with suggestions for policy and research for policymakers and other relevant stakeholders.

\section{Materials and Methods}

Data on dam development in Nigeria is synthesised and published for the first time. Secondary data used in this paper comes from Nigeria's Federal Ministry of Water Resources and the International Commission on Large Dams (ICOLD). Dams and reservoir information contained in the Nigerian compendium of dams, the 1995 and 2014 national water resources masterplan were accessed, with 192 dams identified containing available data from 1923 to 2007 for analysis. Constructed dams in Nigeria are classified according to size: small, medium, and large [26], each having one or more purposes. In this article, water infrastructure refers to that constructed for agriculture, hydroelectric power, and potable water supply [27]. Data analysis was done using quantitative descriptive analysis on the completed dams' dates, geolocation, and categories.

With study limitations, estimates of water resources availability may be inaccurate if based on published information about the existing and completed dams (reservoir capacity). The World Bank's historical water-related metadata on Nigeria only accounts for five out of the over 1400 categories [28]. A few incomplete data for dam sizes, completion dates, owners, and purposes were noted where necessary.

\section{Nigeria and Sub-Saharan Africa-A Short Description \\ Institutions, Legislations, and Policies in Nigeria's Water Governance}

Nigeria's water infrastructure management is designed to address broad developmental problems expressed in the 2016 National water resources policy [27] (see Table A1). Nigeria operates a sectoral approach to water resources management, where different government ministries or parastatals coordinate water resource use and management issues. Administratively, Nigeria divides the country into eight hydrological areas. The Federal Ministry of Water Resources (FMWR) is responsible for the water sector as the institutional body mandated for water resources development (surface and groundwater), water supply and sanitation, irrigation, and drainage, and flood and erosion control. The FMWR discharges its duties through a few institutions such as the River Basin Development Authorities (henceforth, RBDAs), the Nigerian Integrated Water Resources Management Commission, the Nigerian Hydrological Services Agency, and the National Water Research Institute. The Federal Ministry of Environment manages environmental issues around water resources [29]. Several intersectoral and interagency issues arise due 
to functional misfits at various policy implementation levels. The development of Nigeria's water governance-related legislation started as early as 1915, during the colonial era. Water infrastructure development in Nigeria is classified into three periods. First, the precolonial era before the official annexation of indigenous authorities and communities of all parts of present-day Nigeria in 1861. This date marks the beginning of the first colony to be administered by the British, the colony of Lagos. Second, the colonial era. Micheal Crowder, in his book, West Africa under Colonial Rule [19], proposes a timeline starting in 1885 and ending in 1945. However, this article extends the date to 1954, when self-government began for the regional governments. Officially, Nigeria became a country after the amalgamation of the northern and southern protectorates in 1914 by then Governor-General Lord Lugard. Hence, the colonial government referred to in this paper lasted 46 years from 1914 to 1960, when Nigeria gained political independence from Britain. Following Nigeria's independence from Britain in 1960, the creation of the RBDAs in the 1970s marked the earliest post-independence attempt at developing a comprehensive and practical water policy framework in Nigeria [30-32]. The 1999 constitution of the Federal Republic of Nigeria [33] confers national-level water resources policy design and formulation on the federal government. It draws on the Water Resources Decree 101 of 1993, which vested the "rights and control of water in the federal government" [34].

Historically, Nigeria's water policies have often targeted land, water quality, and environmental protection. The initial attempt to create a comprehensive nationwide water management strategy had begun in the early 1970s, but dwindling finances towards the end of the decade made it redundant [35]. Building on the 1992 national water resources masterplan, the 2014 national water resources master plan [23] was the first completed broad and long-term national water governance framework incorporating integrated water resources management (henceforth, IWRM) as a distinctive feature. IWRM equally underpinned the policy framework for the national water policy in 2000, the draft 2004 water policy [36], and the 2016 national water resources policy [27]. The water resources sub-sector development plan [37] designed to tackle cross-sectoral concerns failed to address other equally critical intrabasin challenges such as water/environmental pollution and forestry.

Transboundary surface water flows into Nigeria account for 24 per cent of Nigeria's annual water resources potential ( 88 out of 324 BCM/year). River Niger, River Benue, and Lake Chad are the three major transnational surface water basins in Nigeria [37], with other small to medium-sized rivers along the $1975 \mathrm{~km}$ Nigeria-Cameroon border from the Cameroon-Adamawa mountains, such as the Katsina-Ala River [38], and the Ogun River in the southwest littoral zone. Nigeria's representation in four international basin organisations (see Table A2) equally raises conceptual issues on the importance of transboundary hydropolitical relationships concerning water infrastructure development.

Beyond these challenges, sub-Saharan Africa hosts 33 out of 47 of the United Nations classification of least developing countries (LDCs) [39], each with specific politicaleconomic conditions, political histories and infrastructure development. Three such countries surround Nigeria. Table 1 illustrates Nigeria's position by comparing water-related sectors with some countries in Central Africa. Considering the scale of Nigeria's human and natural resources and capabilities, improved water resources management in Nigeria can improve regional water infrastructure development in West and Central Africa. With the largest economy in Africa regarding nominal GDP [40], Nigeria is an influential leader in the West African subregion. As one of the regional economic communities of the African Union [41], it has several advantages over many of its neighbours.

\section{Historical Development of Water Infrastructure}

\subsection{Precolonial Water Infrastructure Development}

Water scarcity problems in precolonial Nigeria influenced the development of water infrastructure for agriculture or domestic purposes. Samuel Johnson described water scarcity in Ḱetu, an Òyó town as "a place badly watered, their drinking water being miles 
away from the town. The scarcity of water in Ketu has passed into a proverb. "Omi d'oyin ni Ketu ("water becomes honey in Ketu") [42]. In addition to water scarcity, flooding, droughts, and poor water quality determined bulk water production and storage [43]. Large water storage systems consisting of deep underground tanks for storing rain water "which seemed to be made by the hand of man" [44]. Sources of water include open wells and streams, and creeks [42,44]. Wells of four fathoms (24 feet) were recorded in northeast Nigeria, while dykes were constructed to ward off flooding waters in communities [44].

The purpose and use of water infrastructures varied across the country relative to the geographical characteristic of each region. The southern region, a predominantly rain forest area, did not need for developing extensive irrigation infrastructures for agricultural purposes due to the abundance of rainwater and perennial or ephemeral streams.

Table 1. Nigeria's comparative position in water-related sectors with countries in West and Central Africa.

\begin{tabular}{|c|c|c|c|c|c|c|c|c|c|c|c|}
\hline \multirow[b]{2}{*}{ Country } & \multirow{2}{*}{$\begin{array}{c}\text { Population } 5 \\
\text { (2019 } \\
\text { Estimates) } \\
\text { thousands }\end{array}$} & \multirow{2}{*}{$\begin{array}{c}\text { Life } \\
\text { Expectancy } \\
\text { (Years) }\end{array}$} & \multirow[b]{2}{*}{ Fertility Rate } & \multicolumn{2}{|c|}{$\begin{array}{l}\text { Human Development } \\
\text { Index (HDI) }{ }^{3} \text { (2018) }\end{array}$} & \multicolumn{2}{|c|}{$\begin{array}{c}\text { Water }^{2} \\
\text { (2019 Estimates) }\end{array}$} & \multicolumn{2}{|c|}{ Energy $^{1}$} & \multicolumn{2}{|c|}{$\begin{array}{c}\text { Irigation }^{1} \\
\text { (2017 Estimates) }\end{array}$} \\
\hline & & & & $\begin{array}{l}\text { Rank (out } \\
\text { of 189) }\end{array}$ & $\begin{array}{l}\text { Value (out } \\
\text { of } 1 \text { ) }\end{array}$ & $\begin{array}{c}\text { Drinking } \\
\text { Water Access } \\
(\%)\end{array}$ & $\begin{array}{c}\text { Water- } \\
\text { Related } \\
\text { Diseases } \\
\text { (deaths/year) }\end{array}$ & $\begin{array}{l}\text { Production } \\
\text { (MW) }\end{array}$ & $\begin{array}{l}\text { Electricity } \\
\text { Access (\%) }\end{array}$ & $\begin{array}{l}\text { Agricultural } \\
\text { Land } \\
\text { (thousand } \\
\text { Ha) }\end{array}$ & $\begin{array}{c}\text { Irrigated } \\
\text { Area (\% of } \\
\text { Agricultural } \\
\text { Land) }\end{array}$ \\
\hline Nigeria & 200,964 & 48 & 5.5 & 157 & 0.532 & 69 & 177,800 & 12,522 & 59.3 & 70,800 & 0.41 \\
\hline Cameroon & 25,876 & 51 & 4.6 & 151 & 0.556 & 53 & 18,300 & 1600 & 60.1 & 9750 & 0.30 \\
\hline Chad & 15,947 & 46 & 5.8 & 186 & 0.404 & 52 & 14,300 & 215 & 8.8 & 50,238 & 0.06 \\
\hline Niger & 23,311 & 42 & 7.0 & 189 & 0.354 & 58 & 40,300 & 284 & 16.2 & 46,660 & $\mathrm{n} / \mathrm{a}$ \\
\hline $\begin{array}{l}\text { Central African } \\
\text { Republic }\end{array}$ & 4745 & 48 & 4.8 & 188 & 0.367 & 68 & 4300 & 28 & 8 & 5080 & 0.02 \\
\hline $\begin{array}{c}\text { Democratic } \\
\text { Republic of Congo }\end{array}$ & 86,791 & 47 & 6.0 & 176 & 0.457 & 52 & 107,300 & 2472 & 9 & 31,500 & 0.03 \\
\hline
\end{tabular}

Source: Compiled from the following sources: $[45,46]^{1},[21]^{2},[39]^{3},[47]^{4}$, and $[48]^{5}$.

Land cultivation in the Niger-Delta region and other parts along the Niger-Benue trough was watered by flood waters. However, as one progresses towards the semi-arid north, the technology changes to ox-powered wheels and shadoofs (Figure 1) for irrigation and groundwater extraction.

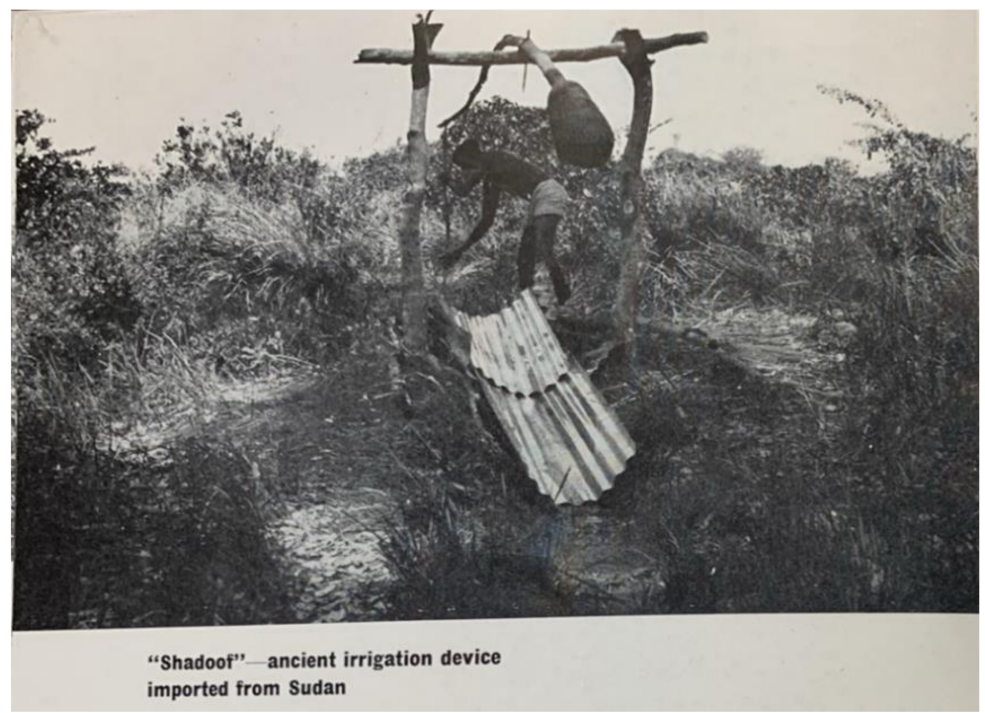

Figure 1. A shadoof [49].

Henry Barth, the famous German explorer, described its use as "drawing up the water in a large leather bag containing a supply sufficient for two horses" [50], a system that suggested that other than human labour, precolonial Nigerians used different technologies for water supply. Domestic water storage and consumption used mortars, calabashes (a type of gourd used for collecting or storing water), rock carvings (Indentations of about 
$2 \mathrm{~cm}$ deep are made into rocks for collecting water and feeding pastures or drinking water), draughts, water skins, water ponds or tebki in Ỳorừbá and Kanuri societies of northern Nigeria $[51,52]$. The production of these water carrying and storage equipment are mostly gendered and created by women. Pottery, for example, was a primarily female industry where high-quality clay, native to large areas of the Ỳorùbá country is turned into large water-storage pots for domestic and sometimes commercial uses $[42,53]$.

\subsection{Colonial and Post-Independence Water Infrastructure Development}

In the Sokoto-Rima basin, the Kware irrigation scheme was Nigeria's first major European style irrigation scheme [54]. The first machine-drilled borehole was bored in 1933 [55], following the construction of the first European style dam with the Lagos water supply scheme in the late 1800s [56]. After six years of self-government from 1954-1960, Nigeria attained independence from the British in 1960. Colonial and post-independence water infrastructure development relied on the national development plans (hereafter, the plans) (see Table A3) and the agricultural development programs (ADPs) as the two main national planning and policy mechanisms. The plans were a set of documents outlining Nigeria's approach to national economic development, starting with the 1946 10-year plan for development to the fifth national development plan 1985-1990 [57]. The ADPs (1974-1997) were agricultural intervention programs created to enhance national development through primary agricultural production and food sustainability $[17,58]$. As the world's largest World Bank development investment program in developing countries at the time, the Nigerian ADPs cost approximately US $\$ 1.2$ billion [59] and contributed tremendously, sometimes beyond planned targets to rural water infrastructural development. A total of 190 dams and 12,651 boreholes and wells were constructed within the 22-year period (see Table A4).

The 1995 national water resources development masterplan (NWRDMP) was the first comprehensive water resources assessment and planning for the entire Country [60], followed by the 2013 national water resources masterplan (NWRMP) [23]. Table 2 shows the distribution of proposed large and medium dams in the 1995 NWRDMP based on the hydrological areas. Financed by a Japanese Government's technical assistance grant through Japan International Cooperation Agency (JICA) [61], the water supply and irrigation component of the 1995 planned to construct a total of 208 large and medium dams as a long term strategy [62].

Table 2. Proposed large and medium dams for irrigation and water supply towards 2020 in 1995 NWRDMP.

\begin{tabular}{ccccccccccc}
\hline Hydrological Area (HA) & HA1 & HA2 & HA3 & HA4 & HA5 & HA6 & HA7 & HA8 & Total \\
\hline JICA & 11 & 49 & 23 & 49 & 14 & 37 & 25 & 0 & 233 \\
\hline RBDA, MANR, SWA & 3 & 25 & 16 & 4 & 0 & 4 & 4 & 0 & 56 \\
\hline
\end{tabular}

Source: [62]. MANR: Ministry of Agriculture and Natural Resources; SWA: State Water Agencies.

These proposed dams (and boreholes) were to increase water supply and irrigation targets to $1.5 \times 10^{6}$ ha and 80 per cent of the population by 2020 [62]. There was also a marked difference between dam development proposal between JICA and RBDA, MANR, and the SWA as the responsible state institutions for water infrastructure development. With this historical overview of water infrastructure development in Nigeria, we can analyse dam purposes, sizes, management and development, and the future of water infrastructure development in Nigeria.

\subsection{Dam Uses and Purposes}

Constructed dams in Nigeria are classified according to size - small $(<5 \mathrm{~m})$, medium $(<10 \mathrm{~m})$, and large $(>15 \mathrm{~m})$ [26,37], with each having one or more purposes. Nigeria's dams provide approximately 40 percent of their water for agriculture-related uses (fishing, livestock rearing, and irrigation) and 40 percent for urban and rural potable water supply (Figure 2). 


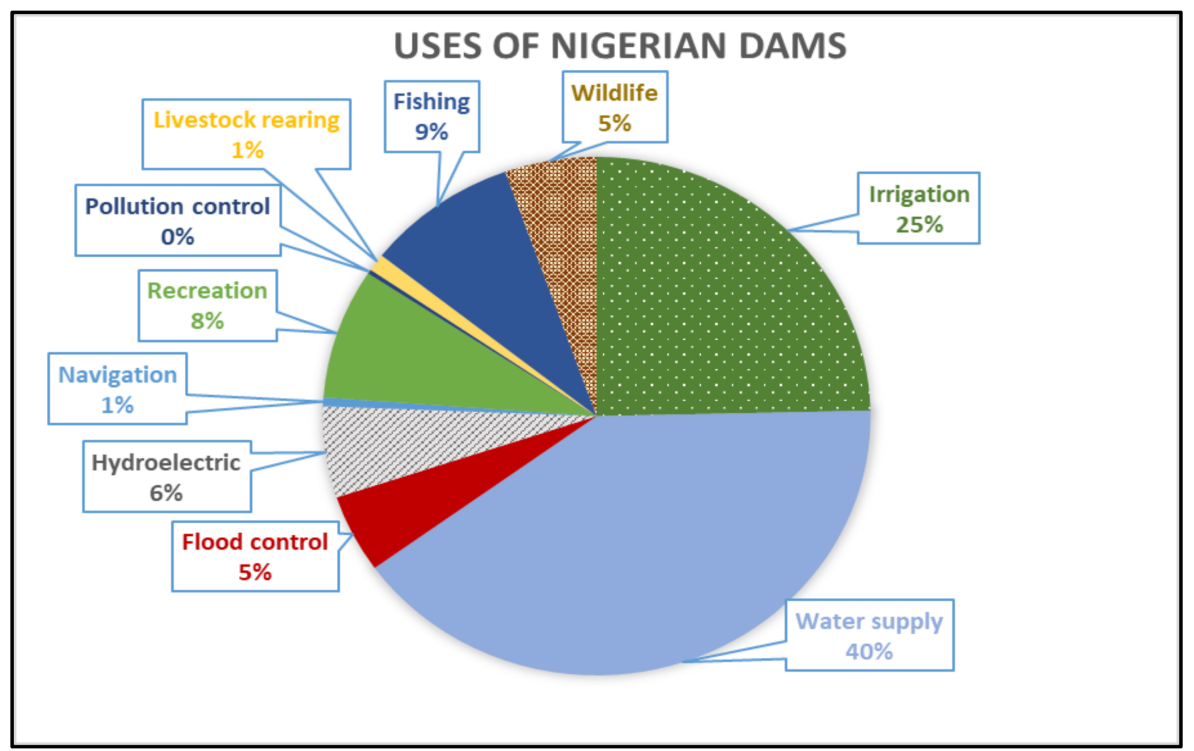

Figure 2. Uses of dams in Nigeria [63].

Irrigation and water supply account for approximately 67 percent of all dams constructed, aligning with the intention of the development plans. In Figure 3, constructed dams for water supply is consistently higher than agriculture purposes since 1960, except in the early 1970s and mid-1980s when the cumulative agriculture number exceeded it. Agriculture purposes consist of irrigation, livestock rearing, and fishing. Agriculture growth is primarily due to the intensification of agriculture development during the oil boom between 1970 and 1998 and the end of the ADPs in the mid-1980s.

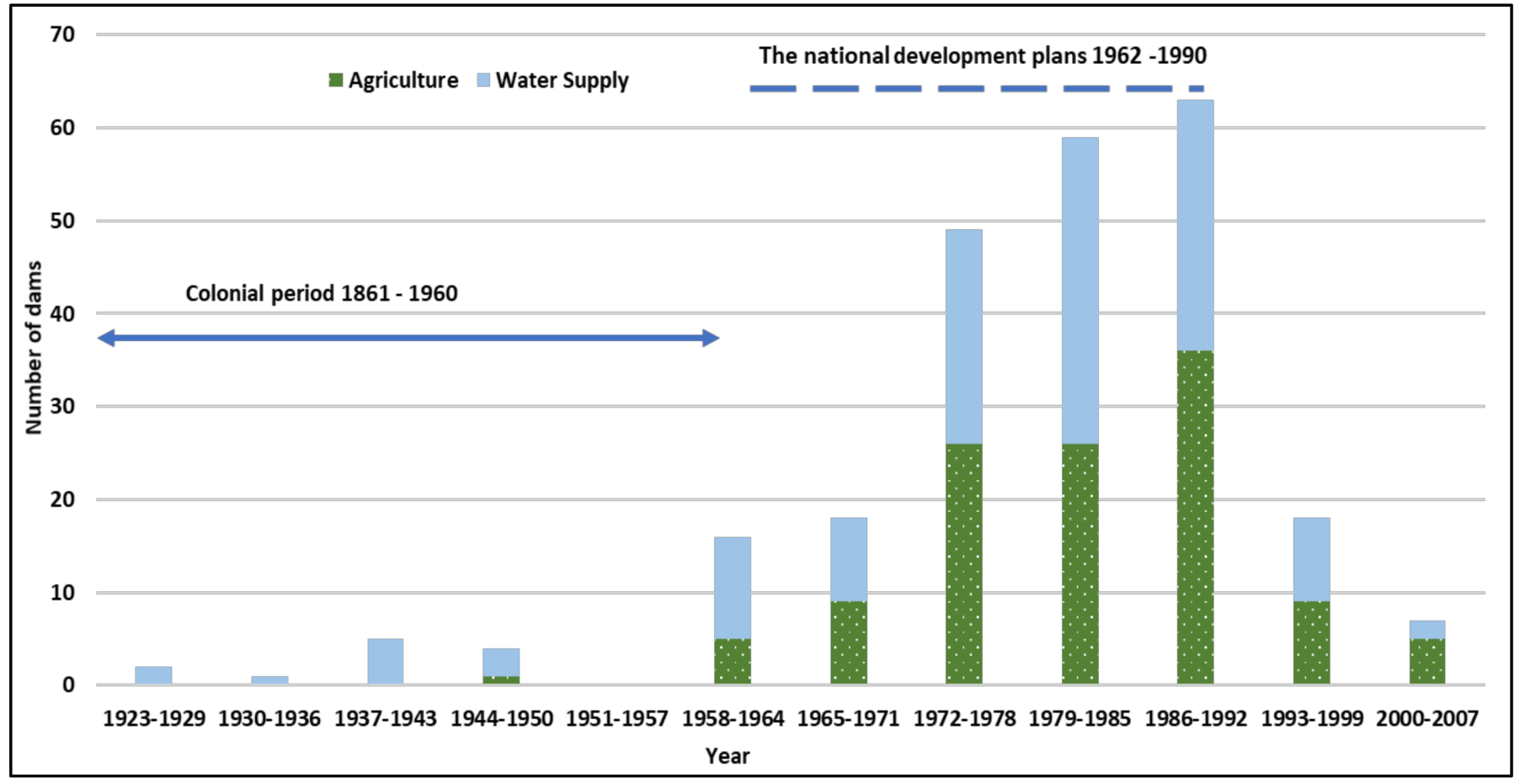

Figure 3. Distribution and trend of dams constructed for water supply and agriculture from 1923-2007 in Nigeria [63].

Furthermore, the declaration of an international drinking water supply and sanitation decade between 1980 and 1990 [64], and some of the supply-side drought management 
strategies of the Nigerian Government [65]. Majority of the constructed dams during this period were multipurpose, which almost always had a water supply component.

Multi-purpose dams (Figure 4) have more than one purpose for their construction and use. Colonial-era dam development focused mainly on welfare and social services such as public water supply and flood control in small towns and other urban centres [66]. The historical pattern of dam purposes indicates the government's direction and intent in developing multipurpose dams. Between 1972 and 1992, 39 percent of dams were multipurpose compared to 30 percent between 1993 and 2007. These figures show that postindependence multipurpose dam development was high aside from the period of the civil war (1967-1970). Contrary to the common idea that the 1970s and 1980s Sahelian droughts did not cause a rise in dam development in Nigeria during that period. Rather, the intensity of dam development, especially for agriculture, was due to a planned developmentalist intervention expressed in the national development plans. These plan's ideological basis originated in the colonial period. Contrary to the common idea that the 1970s and 1980s Sahelian droughts caused a rise in dam development in Nigeria, during that period, the intensity of dam development, especially for agriculture, is principally a planned developmentalist intervention of the national development plans whose ideological basis is dated to the colonial period.

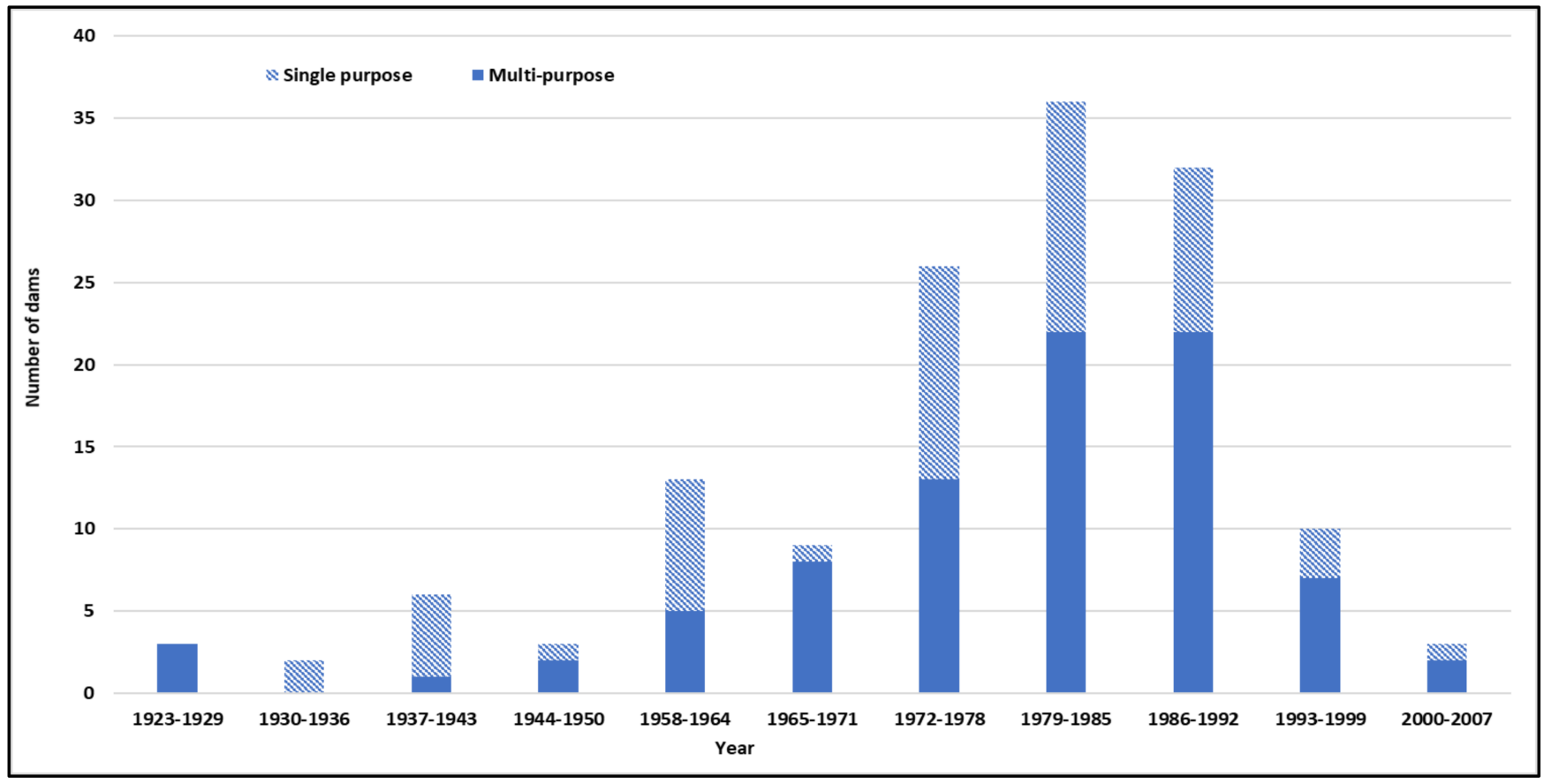

Figure 4. Distribution and trend of multi-purpose and single-purpose dams 1923-2007 [63].

In Figure 5, dam purpose is further disaggregated to show the corresponding number of dams and number of purposes of construction. Noted earlier, the sharp increase in multipurpose dams coincided with the intensification of agricultural and rural development, completion of many of the ADPs, and the pursuit of Nigeria's socio-economic objectives regarding public health and water supply. Approximately one-third of multi-purpose dams have two purposes (water supply and irrigation), representing 30 percent of the total number of all multi-purpose dams. Together, dams with five and six purposes account for approximately 28 percent of all multi-purpose dams. However, 94 percent of these dams are large, while the remaining 6 percent are medium-sized dams. 


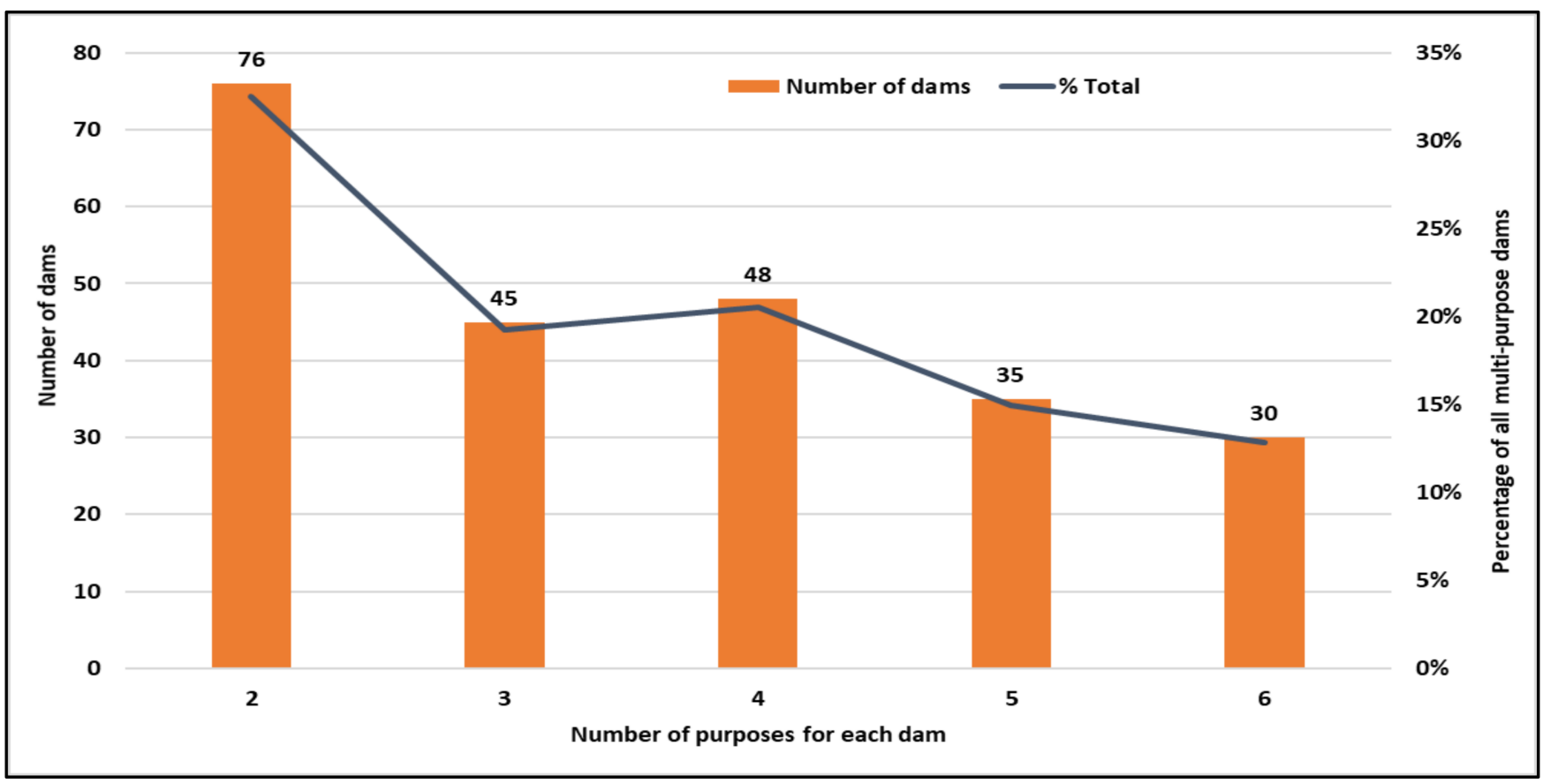

Figure 5. Number of purposes for each dam and percentage of total number of multi-purpose dams.

Figure 6 shows the three main categories of dam construction. The agriculture category sums up all agriculture-related activities (noted in Figure 3), while hydroelectric and water supply are standalone purposes. The dominant occurrence of water supply indicates that substantial financial investments have been made towards water supply development despite the general narrative of underinvestment in water supply infrastructure [67] and the subordination of water supply in government policies.

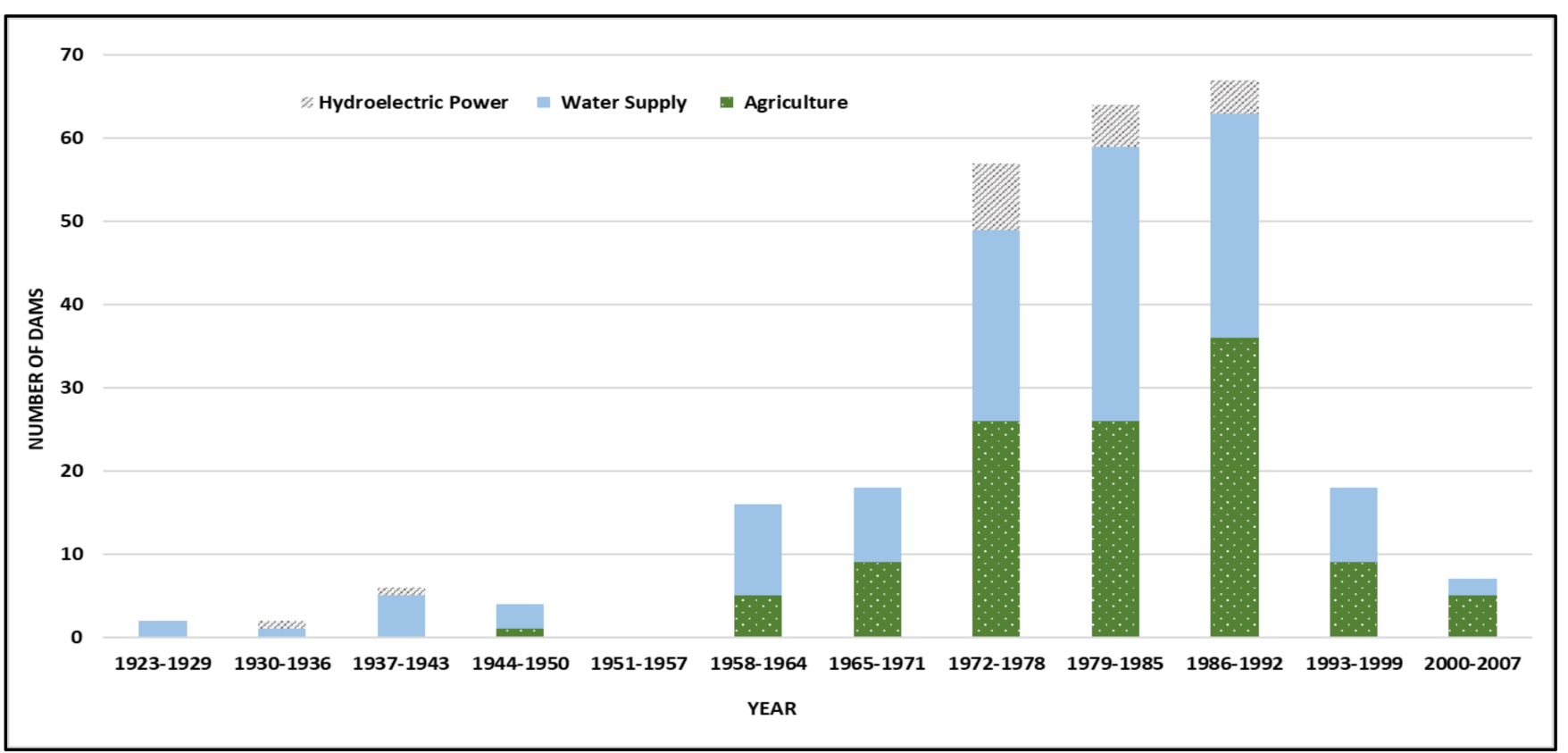

Figure 6. Distribution of completed hydroelectric power, agriculture, and water supply dams 1923-2007 [63].

However, these investments are yet to translate to sustainable water access for the public. Essentially, the dynamics of dam purposes indicates the direction and interests of the Nigerian state and its broader developmental ambitions. 


\subsection{Dam Sizes}

In Figure 7, the historical distribution of dam sizes shows how dams built during the colonial period were mostly small and large until the late 1930s. The passage of the second and third Colonial Development and Welfare Acts facilitated the construction of more dams by enabling a transition from extractive development for the empire to welfare for Nigerians [68]. After the second world war, dwindling financial resources and a lack of technical expertise in the water sector led to reduced dam construction $[69,70]$.

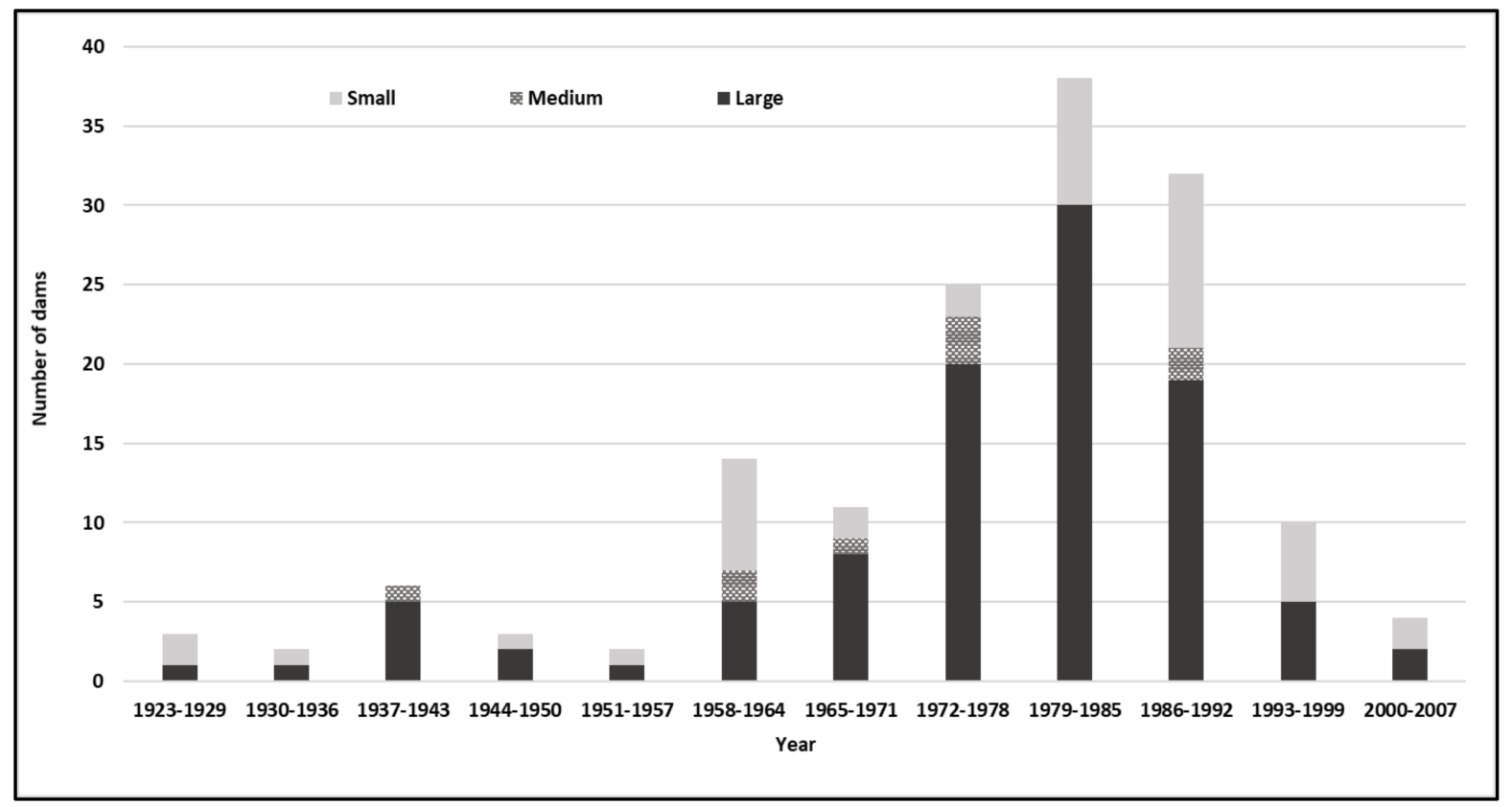

Figure 7. Dam sizes and year in Nigeria 1923-2007 [63].

Dam sizes also indicate the direction of the government's post-independence development intention. For example, the prevalence of large and medium dams suggests an excessive focus on energy generation and agriculture development as in other countries (e.g., Spain, Sudan) [71,72] or increased water supply development for urban centers. Figure 8 shows the spatial distribution of completed dams and the hydrological zones in post-independent Nigeria during different political systems. In the southwestern parts, majority of the dams were completed between 1984 and 1998, where democratic governments were active and civil society was more engaged in public administration.

In addition, the low density of dams in the northeastern parts of the country is tied to the region's endemic infrastructure and urban poverty levels [73] due to the low utilisation of land and other ecological assets [74]. Furthermore, the Sahelian climate with dry arid lands caused by meteorological droughts and variable rainfall meant many seasonal rivers and streams dry out. Drought is exacerbated by climate change [75-77] which diminishes dam development as a viable supply-side strategy.

Despite the impact of the oil glut in the late 1970s and rising debt levels, mainly due to inflationary trends and food imports, the five years of democratic government in the second republic achieved the highest levels of completed large dams. It is also evident that most dams in the country's north were completed during the military regime between 1967 and 1979. As shown in Figure 8, under a democratic government (1979-1984), many of these dams were large dams that followed the development of the ADPs and the water supply decade. 


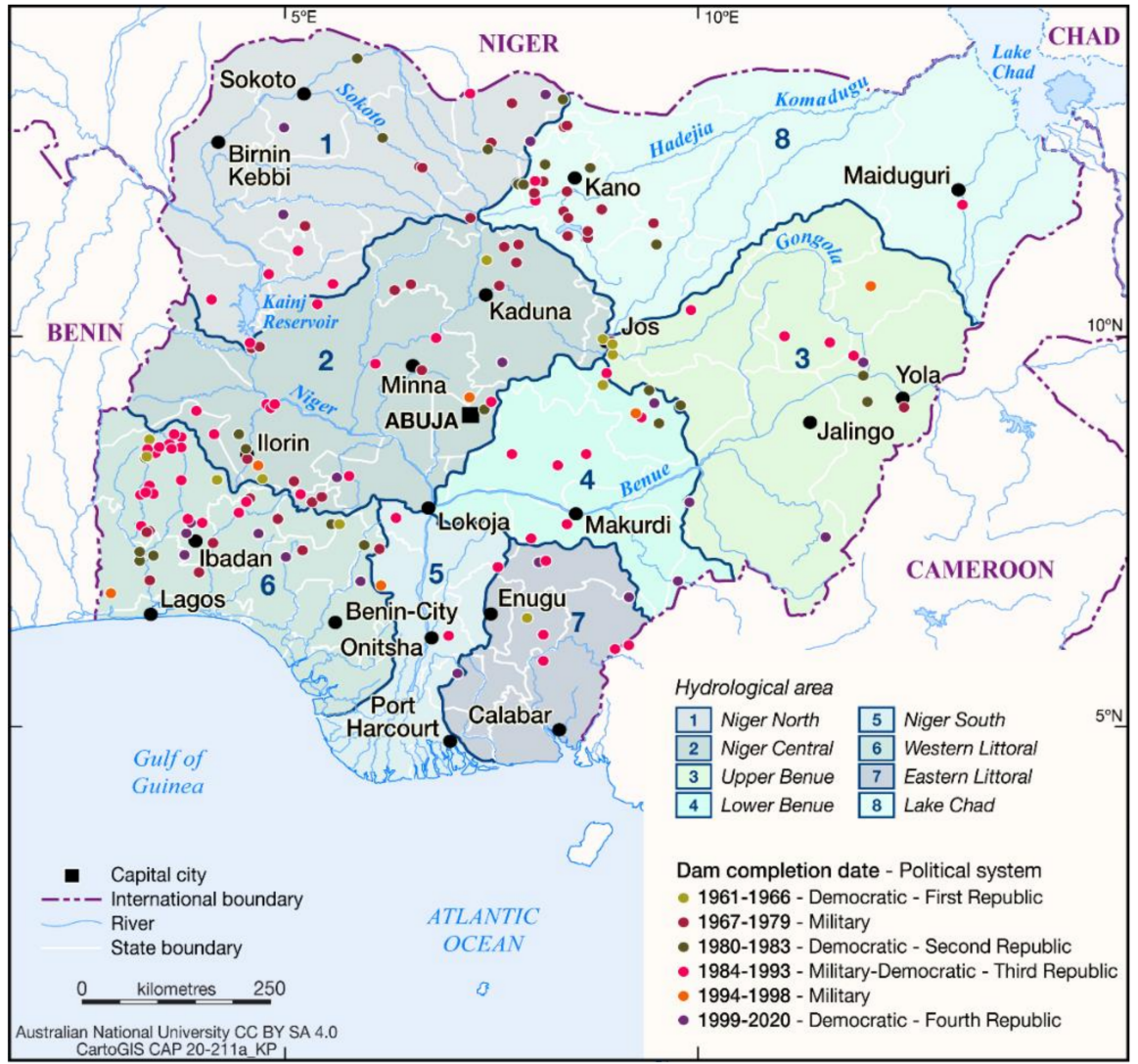

Figure 8. Distribution of completed dams in post-independence Nigeria [37,63].

\subsection{Dam Ownership and Development}

Dam owners, contractors and consultants (Figure 9) in Nigeria form a kind of water elite whose decisions determine the success or failure of dam construction and management [78]. Dam owners have the authority to manage the dam. In some cases, dam owners also act as consultants and contractors to build dams, thereby are responsible for the dam engineering design and construction. Dam contractors build the dams while dam consultants provide technical advice. These dam actors are categorised into two main groups: government and private. Government actors own and manage state-owned construction (e.g., the RBDAs) and consulting agencies (OYSADEP—Òó state agriculture development program), often run like private corporations. Dam contractors can either be state or federal government entities. Private actors are local or foreign businesses that were classified based on the location of their official headquarters.

Dam actors perform a variety of independent or overlapping roles. For example, state or federal government parastatal often owns a dam they construct using state-owned companies as was common in the 1960s and 1970s (e.g., OYSADEP). Figure 9 further shows that the federal and state governments own most dams, whereas contracting and consultancy services are provided mainly by federal agencies and private companies. Arguably, this disproportionate pattern in dam development has implications for the sustainability of water infrastructures. 


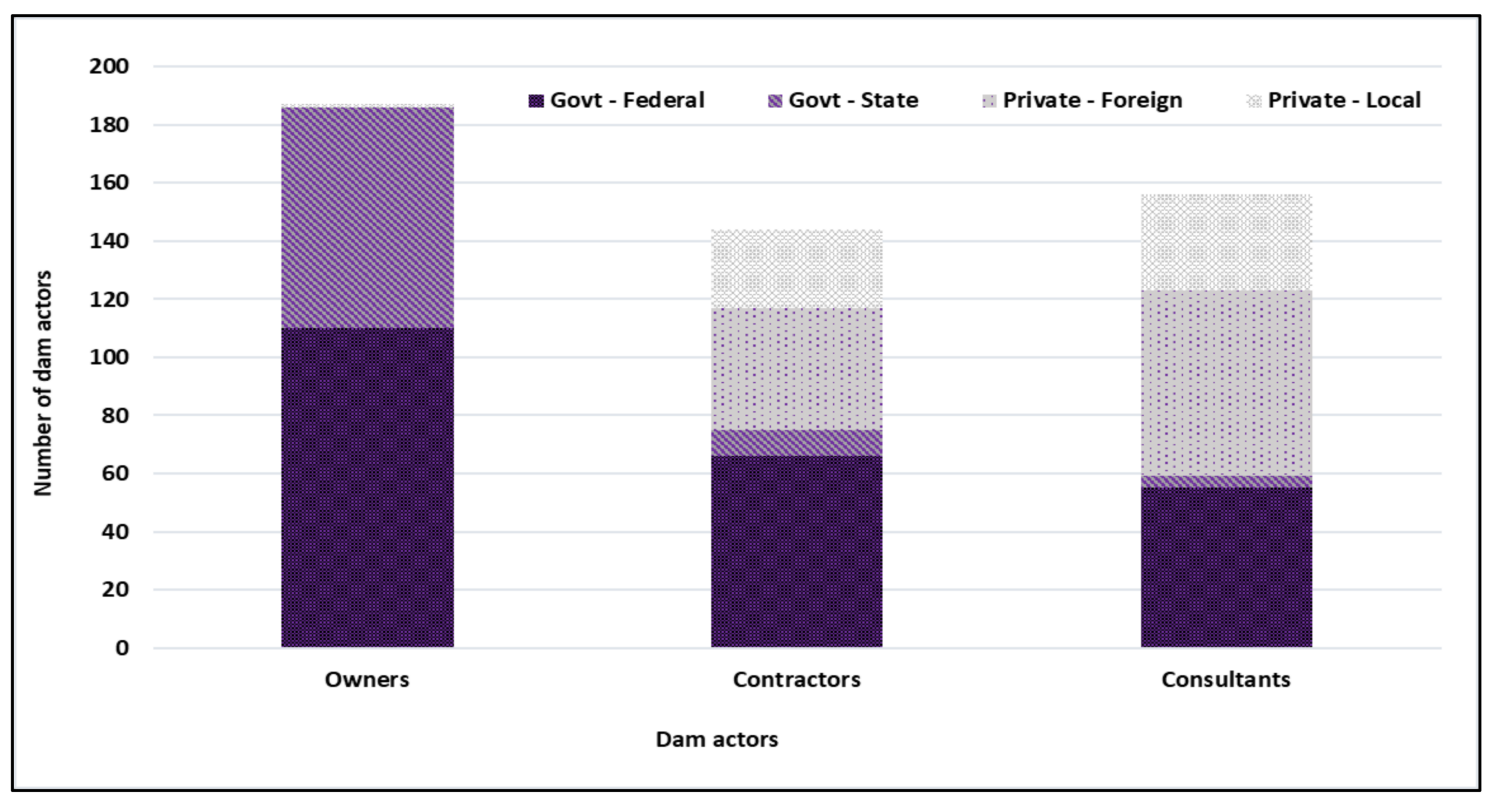

Figure 9. Dam actors: distribution of dam ownership, contractors, and consultants in Nigeria 1923-2007.

\section{Discussions}

\subsection{Infrastructural and Spatial Divisions}

Water infrastructure development in Nigeria has deepened the rural-urban divide due to the differences in water sources and water infrastructure. In policy language and planning, the third plan favoured an integrated rural-urban development approach and aspired to "ensure that no community of 20,000 people or more shall be without essential services" [79]. However, the guideline for the implementation of the plan differentiated between rural and urban water infrastructure development. This distinction is traceable to the colonial government's 10-year development plan in 1946 [80]. Valid at the time, using this distinction as a conceptual pillar was questionable in the 1960s and subsequent years due to the social and infrastructural transformation of rural areas, particularly in transportation [81].

Post-civil war plans for providing rural water supply were driven by 'rural productivity', while urban water supply infrastructure-viewed as social and economic infrastructure-was designed to improve 'urban productivity' [82,83]. Here, water supply infrastructure is perceived as having two distinct roles for the federal government. Rural productivity imagines rural areas and their populations as spatially, temporally, and demographically static entities. This view suggests that their specific sociocultural histories limit their aspirations and needs, while their economic desires are restricted by predetermined cultural and traditional conditions and identities. In other words, rural cultural and traditional belief systems stop rural people from developing their economic potentials. Urban productivity builds on idealised 'growth centres' that seeks to boost the industrial and commercial capacities of new state capitals emerging from newly created states. These conceptual issues have further entrenched the rural-urban divide.

The functionality of water schemes has a regional dimension, with projects in the southern region more likely to fail than in the north over 15 years; 51 percent of these failures are due to fixed variables such as political region and hydrogeology [84]. Water schemes sustainability is comparatively better in the north in terms of greater water access. However, due to increasing levels of internal migration to the southwest, especially Lagos, water utilities are under considerable stress [85]. Fifty-five percent of the total population and over 75 percent of agricultural households in the north live below the poverty line, and the northern part of the country performs below the national average on most development indicators [86]. Despite the presence of most large dams in the north, the functionality of 
water points and water schemes is higher in the north than in the south [87]. Economic poverty is also a delineating factor in the national North-South divide, and the link between water access and material poverty in this regard is established in the literature [88]. The North-South divide has also triggered several debates about federal government infrastructural developmental priorities in agriculture, resources allocation and revenue allocation based on the principle of equitable development used for revenue allocation.

\subsection{Deprioritising Water Supply}

Inherent in its design, Nigeria's first 'national' development plan categorically excluded water resources development and subsumed agriculture development and water resources development under a broad economic development framework. The third and fourth development plans captured water supply in a category of 'social amenities', including medical facilities, schools, and electricity [89]. Pius Okigbo noted the "exclusion of activities like water resources development (for agriculture and industry)" from what the government saw as the productive economic sector [57]. The third plan did not commit adequate funds for effective implementation of socioeconomic inequalities or address critical issues related to water supply despite having a surplus of US\$5.2 billion [90,91]. Unlike the agricultural sector, the first federally initiated and managed urban water supply project occurred in 1992 [92], a 19-year difference between direct federal involvement in water supply. Before this project, the World Bank-supported a range of state urban water supply initiatives and large dam constructions (e.g., the Anambra state water supply project in 1980). The water supply decade focused chiefly on rural water supply infrastructure development with boreholes as the primary water infrastructure (e.g., The National Borehole Program).

\subsection{Political Infrastructures}

Agriculture development through irrigation was historically a central pillar of development planning and intervention in Nigeria [57,93]. Sahelian droughts are a historical reality for Northern Nigeria who sees water resources and irrigation development as a "basic natural resource" for economic development [94]. Colonial-era irrigation systems were constructed to control farmers' productivity [70] while simultaneously ignoring existing local wetland irrigation practices [95-97]. The Northern Region Development Programme 1962-1968 dedicated 838,000 Pounds for irrigation development in the Sokoto-Rima valley as part of this agenda [94]. Similarly, the federal government's anti-drought management strategy in 1973 hinged upon a short and long-term approach. The short term approach provided a US\$13.3 million welfare grant to four northern states affected by the drought, while the long term strategy aimed to construct grain stores, increase grain production, and establish the 250,000 tons National Strategic Grains Reserve stipulated in the third plan $[98,99]$.

Two crucial factors determine the further decline in the dam numbers during the 1990s. First, the political instability arising from the complex military/democratic structure had begun to show the fractures inherent in such a system due to the increasing pressure on General Babangida to hand over power to a democratic president. This initial pressure spiralled into the 1993 annulment that led to a transitional government and eventual take over by Gen. Sani Abacha. The second point relates to the end of the World Bank ADPs in 1993. These political changes meant that the multistate ADPs had to adjust to the flow-on effect of the corresponding policy and institutional changes like the new states' commodity boards, which were often technically, financially and administratively ill-equipped to manage the ADPs [100]. Even though the ADPs did not prioritise water supply, there were 'unintended positive consequences' for rural water supply going by the success of the water supply component of the programme [101]. The water supply components consisted of small dams, wells, and public standpipes.

The political problems are also linked to the corresponding management challenges, which the GWP-N (Global Water Partnership-Nigeria) considers a critical governance 
problem in Nigeria. By asking to identify the 'main actors in water service provision, their interests and those of the stakeholders involved' [102], the GWP-N seeks to understand the allocation of power in the relations between various stakeholders invested in water infrastructure. Governance responses also prioritise the technical, financial, and technological manipulation and modification of governance systems, ecologies, and infrastructure [103-106] at the expense of narratives, policies, and governance practices that consider the local context [32]. Such responses include expanding water storage and access capacities by building more dams and boreholes $[24,33,107]$ and constructing the additional 370 dams noted earlier [107].

\subsection{Infrastructure Failures and Sustainability}

Water project failures are a crucial challenge in Nigeria. For example, in the rural water supply sector, functionality and sustainability as concepts are scrutinised due to the preponderance of failed water projects $[84,87,108]$. The FMWR observed that 116 projects were still uncompleted or ongoing after an average of 15 years since commencement; 38 irrigation and drainage projects, 37 dam projects, and 41 water supply projects [109]. An estimated 46 percent of water schemes (water schemes are water supply projects with drinking water as the main water component) are non-functional in Nigeria [84]. The failure of these utilities impacts water access geographically, manifestly in the ruralurban dichotomies and differences [108,110] and at the household level [111]. In addition, existing water infrastructure cannot sustain current population growth due to the rate of infrastructural deterioration and low infrastructural investment [86].

Nevertheless, the federal government plan to construct additional 370 dams (10 dams in each state and the federal capital territory) in the country over the next four years [107]. This ambition demonstrates a lack of reflection on what the Global Water PartnershipNigeria described as the "underlying causal factors of infrastructure deterioration and decay to militate against a repeat of similar problems in the future" [102]. Ultimately, project failures cannot be divorced from the question of power and equitable distribution, or the politicisation of these infrastructure projects' stakeholders, mechanisms, and governing processes.

\subsection{Infrastructure Classification and Typologies}

In Nigeria and globally, dams and reservoirs are usually classified in size and capacity [8]. Standpipes and dams in Nigeria are still classified as technological entities [112] despite evidence for the sociotechnical nature of its development, use, and management [113-116]. Taps, dug wells, and standpipes classified for potable water supply [117] raises questions about the source-infrastructure conundrum. A lack of a clear theoretical definition of what constitutes a water infrastructure (a Google search of "what is a water infrastructure?" showed 257 results) becomes a specific problem for developing countries due to the different water governance systems, repeated malfunctioning of water infrastructure [12], and multiplicities of technologies [118].

\subsection{Optimal Use of Water Resources and Infrastructure}

Nigeria's 8600 inland waterways [119] offer several social and economic development opportunities which can be channelled to increase economic opportunities. However, agriculture and water supply account for seventy-five percent of dam construction in Nigeria, while energy, the bedrock of any nation's economic development, sits at six percent (Figure 3). In contrast to seventy percent for rich countries, Africa's current hydroelectric potential development remains at approximately three percent [120]. With navigation, colonial historical records show that the Benue River was navigable all year round in the 19th century [121]. Nevertheless, efforts to dredge the lower Niger river has met with fierce resistance from downstream water users.

Water-related tourism is another potential area for economic development. The World Travel \& Tourism Council's report predicts that the Nigerian tourism industry will grow 
to approximately two percent of GDP by 2028 [122]. Tourism's potential socioeconomic and political impact could be harnessed to mitigate conflicts and aid post-conflict environments [123-125]. Dams and other water bodies possess potential as tourism infrastructures [126]. Increased optimisation of these resources could raise additional pressures (and opportunities) for different regions and states in Nigeria. However, the opportunities this presents could be effectively harnessed with a conceptual perspective that situates people and power at the forefront of resource use and management.

\subsection{The Future of Water Infrastructure Development}

Figure 10 shows a state-by-state outline of new and rehabilitated boreholes for water supply and agriculture planned to achieve SDG 6 and the regional disparities across the states (see Table A5). Standpipes are a component of a water supply scheme where people gather around a pipe to access water for domestic and commercial uses but also irrigation purposes.

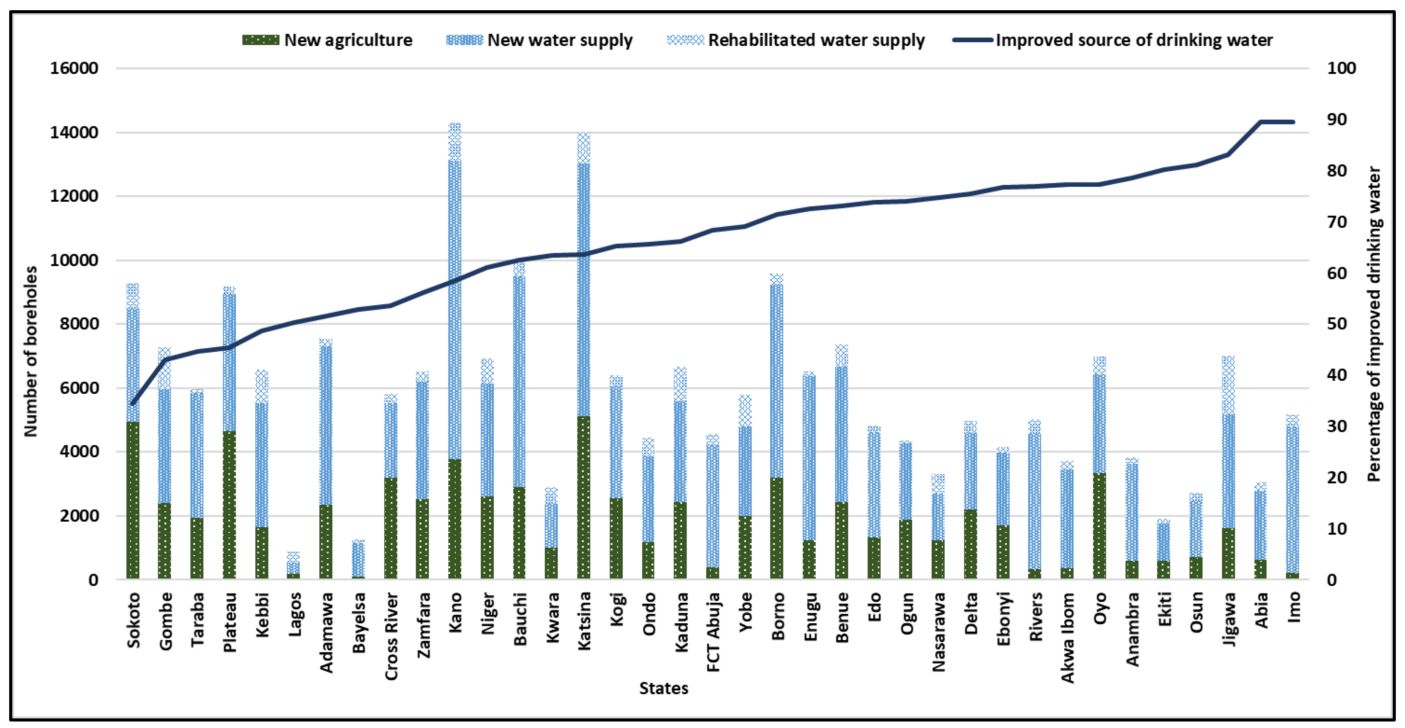

Figure 10. New and rehabilitated boreholes to meet SDG 6 in 2030: Improved drinking water sources and agriculture needs in Nigerian states [127].

Water from standpipes is primarily sourced from groundwater but also reticulated systems from dams. Standpipes in this paper include tubewells, boreholes, protected wells, public taps, and protected springs [128]. These reflect the range of 'hardware' components used to meet Nigeria's SDG 6 long-term strategy of achieving full access to water by 2030 [129]. It is also conceptualised differently to water governance, use, and construction of dams because the community management model is the standard management framework for most water points in Nigeria. States like Imo, Abia, and Jigawa with approximately 90 percent improved drinking water rates will build new water supply boreholes in equal numbers as Taraba, Gombe, and Sokoto in the North with over 50 percent margin in improved water access. Eight northern states (Borno, Adamawa, Bauchi, Kaduna, Kano, Katsina, Zamfara, and Sokoto) account for 38 percent of the new boreholes to be constructed for agriculture, while Lagos, the most populous state in Nigeria (22 million) and ranking 31 out of 36 states on water access, has the lowest number of new boreholes to be constructed for water supply. The variations on newly constructed boreholes across states and Abuja demonstrate how investments by states with lower water access rates can entrench the spatial inequities in water infrastructure and water access.

With dams, the 2013 NWRMP proposes 81 new and ongoing dams to be constructed and plan to rehabilitate 87 existing dams [37]. However, the NWRMP contained no description of the technological choices. Therefore, it misses the opportunity to embrace less 
ecologically disruptive technologies such as "zero head" used predominantly in China and India [130]. Recent studies on the role of dams (especially small dams) in developing countries suggest that small scale dam development for small towns water supply development could facilitate the achievement of the SDGs [131]. Although opinions are divided on whether Africa should pursue a dam-driven 'green' infrastructure trajectory, most of these studies disproportionately focus on large dams while reports of social and ecological damages caused by small dams remain to be assessed [130]. Despite the historical problems, effective development of small and medium scale dams is promising for a sustainable future for water supply, agriculture, and hydropower development [132]. Moreover, increases from such development fit conceptually into the broader African infrastructure agenda proposed in the Programme for Infrastructure Development in Africa (PIDA) framework [133].

Effective development here means focussing on what is variously called 'nature based solutions; and 'ecosystem based adaptation', e.g., restoring water catchments as suggested by the United Nations in Valuing Water [7]. Rehabilitating existing, failed, and deteriorating dams, and their catchments to support current climate mitigation efforts, especially in the north west of Nigeria. Better management of groundwater as a different water source as there are indication that the Sahelian and Niger basin groundwater stock is increasing $[134,135]$. Supporting Indigenous knowledge systems to improve local rainwater harvest and conservation agriculture. Lastly, encourage a more efficient use of existing water and return environmental flows. These options will set Nigeria on a different path from its past, for a more sustainable future where social, economic, ecological resources form the basis of future water infrastructure development.

\section{Conclusions}

This article presents a historical outline of water infrastructure development in Nigeria with a specific focus on dam management and development, dam sizes, and dam use and purpose using data from the Nigerian compendium of dams 2007 and the 1995 and 2014 national water resources masterplan. In addition to the national development plans, the national water resources development masterplan (1995 and 2013) and the agriculture development programs (ADPs) are the two post-independence policy documents and frameworks that distinctly underpin water infrastructure development in Nigeria. The subordination of water supply infrastructural development to agricultural development at the national level until the early 1990s was evident in the four national development plans and investment in agricultural development programs. The inadequate attention to, and unequal treatment of, rural water supply in the development discourse is apparent and affects livelihoods. A lack of intentional design and poor conceptualisation forces rural populations to bear the brunt of delayed, deteriorated, and failed water infrastructure.

Based on this assessment, priorities for more sustainable water resources development include:

- Reimagining how water infrastructure is optimally used in both the productive and non-productive sectors. Tourism and small-scale hydroelectric production capacities of the small and medium dams should be explored.

- Contemporary rural-urban development approaches that are coherent and integrative to reflect the blurred geographical and infrastructural boundaries that previously separated peoples. These spatial differences are evident in the differentiated access to water between the southern and northern parts of the country and rural and urban areas.

- Infrastructure development options must remain flexible enough to cater for an uncertain future in terms of population growth, economic needs, and climate change [136].

- Actors involved in policy planning, formulation and implementation should invest more to understand the power relations and political dimensions of water infrastructure development, specifically, in its spatial allocation, financing, and budgetary investments. 
A synergy between researchers, the private sector, and government at all levels can facilitate more sustainable water resources development by drawing on existing financial, technical, and regulatory knowledge and opportunities at local, regional, and international levels [137].

Three areas of future research emerge from this study. First, there is a need to better document and monitor dams, reservoirs, and other water infrastructure in Nigeria. Such systematic data collection would ensure more accurate estimates of Nigeria's water storage capacity and establish exact stages of infrastructural failure, deterioration, or accretion. Second, the validity and sustainability of current rural water supply strategies overwhelmingly provided through wells and boreholes require further investigation as unsustainability appears to be an intrinsic attribute of this model of development. Finally, further research is needed to examine how power asymmetries between federal, state, and local governments can improve effectiveness and the increased roles of non-state actors in water infrastructure development and management. Such structural adaptations are necessary for large scale transformation; however, more research on this sociopolitical aspect is urgently needed.

Author Contributions: Conceptualization, A.A.; Data curation, A.A., K.A.D. and J.P.; Formal analysis, A.A.; Visualization, K.A.D., A.A.; Writing-original draft, A.A.; Writing-review \& editing, A.A.; K.A.D. and J.P. All authors have read and agreed to the published version of the manuscript.

Funding: This work was supported by the Australian National University [PhD grant].

Institutional Review Board Statement: The research for this paper was approved under ANU HREC protocol number 2016/677.

Informed Consent Statement: Not applicable.

Data Availability Statement: The study reported no data, please exclude.

Acknowledgments: We thank the two anonymous reviewers.

Conflicts of Interest: The authors declare no conflict of interest.

\section{Appendix A}

Table A1. Current challenges in water resource management [27].

i. Unevenly distributed water resources and demand necessitating the creation of dams and transportation of water to the areas of need.

ii. Inadequate access to usable water resources to meet the rapidly increasing domestic and industrial (economic growth) water demand. These are manifested by poor access to clean and potable water in urban, small towns and rural areas, low levels of irrigation agriculture, poor utilisation of hydropower potentials and limited inland fishery.

iii. Degrading watershed and water courses as a result of widespread pollution, including the indiscriminate disposal of hazardous wastes due to poor pollution and mining control leading to deteriorating water quality.

iv. Fragmented and uncoordinated water resources development as a result of inadequate catchment management.

v. Unclear roles and responsibilities among the various levels of government, different ministries, departments and agencies at the federal and state levels.

vi. Poor coordination (including international donor coordination), mobilisation and application of funds for water supply development. This often leads to duplication of efforts, wastages, and inefficiency in the development and management of water infrastructure throughout the country vii. Inadequate water resources data collection and management. This leads to poor planning and project designs.

viii. Limited groundwater availability in the areas underlain by crystalline rocks which covers substantial parts of the country, while for the more productive sedimentary areas of the country, detailed study and documentation is still premature.

ix. Poor or lack of monitoring and control of groundwater resources.

x. Escalating costs of water production and distribution for domestic and industrial water supply, irrigation, husbandry, horticulture and other uses against dwindling financial resources.

xi. Inefficient government subsidies on the provision water services.

xii. Extreme weather conditions due to climate change resulting in prolonged droughts, increased flooding, widespread erosion, and communal conflicts.

xiii. Vicious cycle of unreliable projects that provide services that do not meet consumer needs and for which the consumers are unwilling to pay. xiv. Poor or inefficient management of water resources infrastructures like dams, reservoirs, waterworks with their related distribution networks, irrigation structures, and navigable waterways leading to financial losses and unreliable service delivery. 
Table A2. Nigeria's transboundary organisations. Source: Authors.

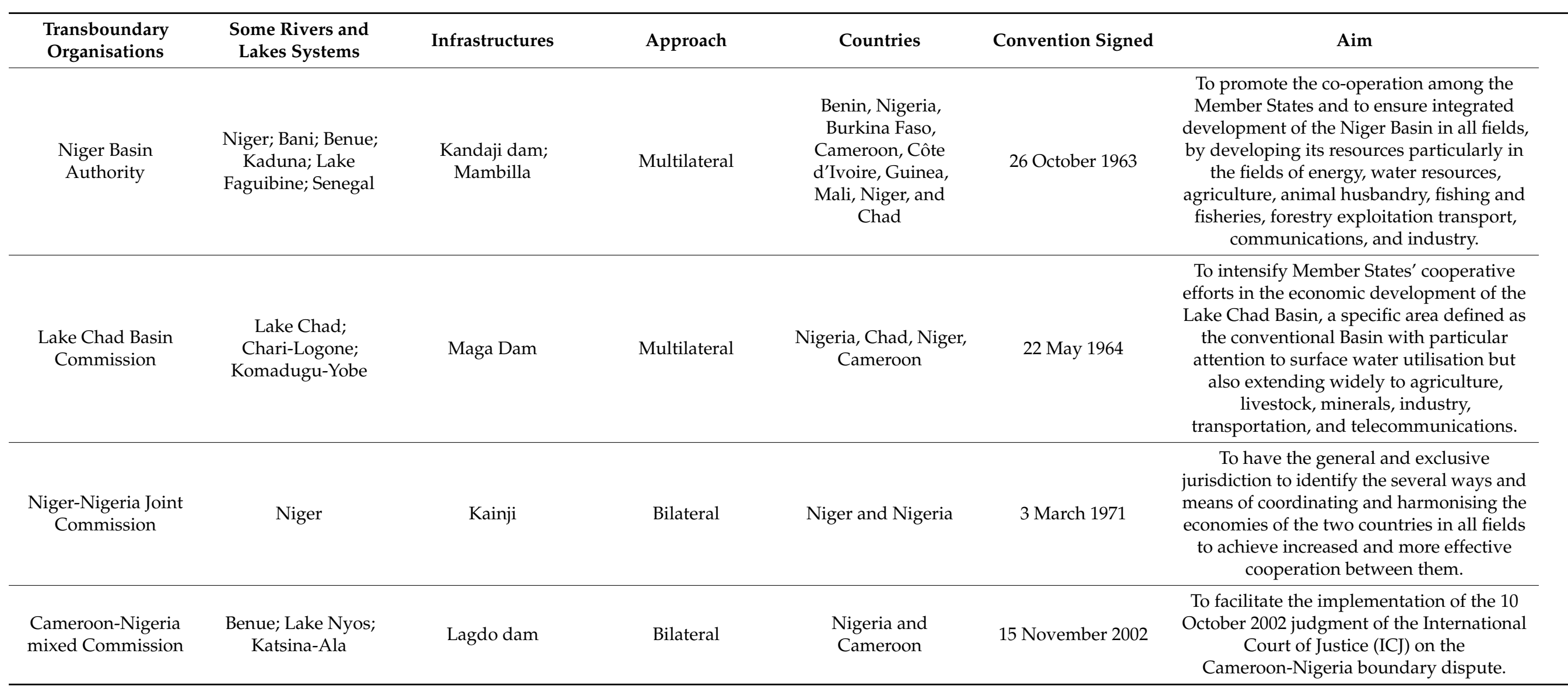


Table A3. Federal government capital expenditure for water and agriculture in the national development plans. Source: Authors.

\begin{tabular}{ccccc}
\hline Plan & Years & $\begin{array}{c}\text { Projected } \\
\text { Resources (N } \\
\text { million) }\end{array}$ & $\begin{array}{c}\text { Water (Other } \\
\text { than Irrigation) } \\
\mathbf{( \% )}\end{array}$ & $\begin{array}{c}\text { Agriculture } \\
\mathbf{( \% )}\end{array}$ \\
\hline 10-Year plan & $1945-1955$ & NA & NA & NA \\
\hline Development programs & $1955-1961$ & NA & NA & NA \\
\hline First & $1962-1968$ & 2434 & 3.6 & 13.6 \\
\hline Second & $1970-1974$ & 9051 & 5.8 & $\mathrm{n} / \mathrm{a}$ \\
\hline Third & $1975-1980$ & 43,783 & 2.8 & 5.0 \\
\hline Fourth & $1981-1985$ & 96,968 & 0.4 & 11.1 \\
\hline Fifth & $1988-1992$ & $\mathrm{n} / \mathrm{a}$ & $\mathrm{n} / \mathrm{a}$ & $\mathrm{n} / \mathrm{a}$ \\
\hline
\end{tabular}

Table A4. The World Bank Agricultural Development Programs. Source: Authors.

\begin{tabular}{|c|c|c|c|c|c|c|c|c|c|c|c|}
\hline & \multirow{3}{*}{ Program Name } & \multirow{3}{*}{$\begin{array}{l}\text { Loan } \\
\text { Amount } \\
\text { (US\$ } \\
\text { million) }\end{array}$} & \multirow{3}{*}{$\begin{array}{c}\text { Loan } \\
\text { Approval } \\
\text { (Year) }\end{array}$} & \multirow{3}{*}{$\begin{array}{l}\text { Loan } \\
\text { Closed } \\
\text { (Year) }\end{array}$} & \multirow{3}{*}{$\begin{array}{c}\text { Completed } \\
\text { (Year) }\end{array}$} & \multicolumn{4}{|c|}{ Water Supply Component } & \multicolumn{2}{|c|}{ Project Evaluation Ratings } \\
\hline & & & & & & \multicolumn{2}{|c|}{ Planned } & \multicolumn{2}{|c|}{ Completed } & \multirow{2}{*}{ Sustainability } & \multirow{2}{*}{$\begin{array}{c}\text { Overall } \\
\text { Assessment }\end{array}$} \\
\hline & & & & & & Dams & Others & Dams & Others & & \\
\hline \multirow{9}{*}{$\begin{array}{c}\text { First } \\
\text { generation: } \\
\text { Enclave ADPs }\end{array}$} & Funtua ADP & 29 & 1974 & 1982 & 1982 & 85 & 0 & 45 & 0 & Likely & Satisfactory \\
\hline & Gusau ADP & 19 & 1974 & 1982 & 1982 & 85 & 0 & 47 & 0 & Likely & Satisfactory \\
\hline & Gombe ADP & 21 & 1974 & 1982 & 1982 & 85 & 0 & 40 & 0 & Likely & Satisfactory \\
\hline & Lafia ADP & 27 & 1977 & 1984 & 1985 & 0 & 400 & 0 & 259 & Unlikely & Unsatisfactory \\
\hline & Ayangba ADP & 35 & 1977 & 1985 & 1985 & 0 & 0 & 0 & 24 & Unlikely & Unsatisfactory \\
\hline & Bida ADP & 23 & 1979 & 1987 & 1990 & 0 & 0 & 0 & 0 & Unlikely & Satisfactory \\
\hline & Ilorin ADP & 27 & 1979 & 1988 & 1992 & 0 & 0 & 0 & 0 & Uncertain & Unsatisfactory \\
\hline & Oyo North ADP & 28 & 1980 & 1988 & 1989 & 40 & 300 & 12 & 1391 & Uncertain & Unsatisfactory \\
\hline & Ekiti-Akoko ADP & 32.5 & 1980 & 1986 & 1986 & 35 & 0 & 0 & 0 & Uncertain & Unsatisfactory \\
\hline Total & & 241.5 & & & & 330 & 700 & 144 & 1674 & & \\
\hline \multirow{5}{*}{$\begin{array}{l}\text { Second } \\
\text { generation: } \\
\text { State-wide } \\
\text { ADPs }\end{array}$} & Bauchi state ADP & 132 & 1981 & 1989 & 1989 & 25 & 1300 & 0 & 1480 & Uncertain & Satisfactory \\
\hline & Kano state ADP & 142 & 1981 & 1989 & 1990 & 0 & 1000 & 0 & 1659 & Uncertain & Satisfactory \\
\hline & Sokoto state ADP & 147 & 1982 & 1990 & 1990 & 0 & 1200 & 32 & 3500 & Uncertain & Unsatisfactory \\
\hline & $\begin{array}{c}\text { Kaduna/Katsina } \\
\text { ADP }\end{array}$ & 122 & 1984 & 1994 & 1995 & 48 & 1420 & 9 & 1302 & Uncertain & Satisfactory \\
\hline & South Borno ADP & 25 & 1986 & 1994 & 1994 & 0 & 910 & 0 & 437 & Likely & Satisfactory \\
\hline Total & & 568 & & & & 73 & 5830 & 41 & 8378 & & \\
\hline \multirow{3}{*}{$\begin{array}{l}\text { Third } \\
\text { generation: } \\
\text { Multistate } \\
\text { ADP }\end{array}$} & $\begin{array}{c}\text { First Multistate } \\
\text { ADP }\end{array}$ & 162 & 1986 & 1995 & 1995 & 0 & 2574 & 0 & 1684 & Likely & Satisfactory \\
\hline & $\begin{array}{c}\text { Second Multistate } \\
\text { ADP }\end{array}$ & 85.2 & 1989 & 1995 & 1995 & 0 & 975 & 0 & 443 & Likely & Satisfactory \\
\hline & $\begin{array}{c}\text { Third Multistate } \\
\text { ADP }\end{array}$ & 100.9 & 1989 & 1996 & 1997 & 37 & 970 & 5 & 472 & Uncertain & Satisfactory \\
\hline Total & & 348.1 & & & & 37 & 4519 & 5 & 2599 & & \\
\hline Grand Total & & 1157.6 & & & & 440 & 11,049 & 190 & 12,651 & & \\
\hline
\end{tabular}

Table A5. Number of newly drilled borehole to meet water demand of 2030. Source: [37].

\begin{tabular}{|c|c|c|c|c|c|c|c|c|}
\hline \multirow[b]{3}{*}{ State } & \multirow{2}{*}{\multicolumn{3}{|c|}{$\begin{array}{c}\text { Urban/Semi-Urban/Small Town } \\
\text { Motorised Pump }\end{array}$}} & \multicolumn{4}{|c|}{ Rural } & \multirow[b]{3}{*}{ Overall Total } \\
\hline & & & & \multicolumn{3}{|c|}{ Motorised Pump } & \multirow[t]{2}{*}{ Hand Pump } & \\
\hline & $200 \mathrm{~m}$ & $50 \mathrm{~m}$ & Total & $200 \mathrm{~m}$ & $50 \mathrm{~m}$ & Total & & \\
\hline Abia & 108 & 215 & 323 & 78 & 63 & 140 & 1217 & 2144 \\
\hline Adamawa & 29 & 546 & 575 & 50 & 295 & 345 & 3116 & 4956 \\
\hline Akwa Ibom & 133 & 45 & 178 & 215 & 34 & 249 & 2242 & 3096 \\
\hline Anambra & 71 & 76 & 147 & 189 & 54 & 243 & 2266 & 3046 \\
\hline Bauchi & 141 & 333 & 474 & 234 & 270 & 504 & 4661 & 6617 \\
\hline Bayelsa & 208 & 0 & 208 & 56 & 0 & 56 & 542 & 1070 \\
\hline Benue & 16 & 218 & 234 & 23 & 326 & 349 & 3066 & 4232 \\
\hline Borno & 353 & 303 & 656 & 311 & 106 & 418 & 3910 & 6057 \\
\hline Cross River & 18 & 161 & 179 & 40 & 145 & 185 & 1595 & 2323 \\
\hline
\end{tabular}


Table A5. Cont.

\begin{tabular}{|c|c|c|c|c|c|c|c|c|}
\hline \multirow[b]{3}{*}{ State } & \multirow{2}{*}{\multicolumn{3}{|c|}{$\begin{array}{c}\text { Urban/Semi-Urban/Small Town } \\
\text { Motorised Pump }\end{array}$}} & \multicolumn{4}{|c|}{ Rural } & \multirow[b]{3}{*}{ Overall Tota } \\
\hline & & & & \multicolumn{3}{|c|}{ Motorised Pump } & \multirow[t]{2}{*}{ Hand Pump } & \\
\hline & $200 \mathrm{~m}$ & $50 \mathrm{~m}$ & Total & $200 \mathrm{~m}$ & $50 \mathrm{~m}$ & Total & & \\
\hline Delta & 208 & 0 & 208 & 178 & 0 & 178 & 1612 & 2384 \\
\hline Ebonyi & 0 & 0 & 0 & 4 & 203 & 206 & 1867 & 2280 \\
\hline Edo & 145 & 234 & 379 & 139 & 95 & 234 & 2078 & 3304 \\
\hline Ekiti & 0 & 101 & 101 & 0 & 88 & 88 & 792 & 1170 \\
\hline Enugu & 95 & 1180 & 1275 & 79 & 165 & 244 & 2087 & 5125 \\
\hline Gombe & 33 & 525 & 558 & 53 & 169 & 221 & 2011 & 3570 \\
\hline Imo & 212 & 243 & 455 & 226 & 98 & 324 & 3014 & 4572 \\
\hline Jigawa & 317 & 210 & 527 & 176 & 49 & 225 & 2044 & 3548 \\
\hline Kaduna & 2 & 168 & 170 & 1 & 246 & 248 & 2298 & 3133 \\
\hline Kano & 26 & 542 & 568 & 115 & 596 & 711 & 6804 & 9362 \\
\hline Katsina & 335 & 975 & 1310 & 143 & 325 & 468 & 4328 & 7884 \\
\hline Kebbi & 228 & 278 & 506 & 161 & 109 & 270 & 2317 & 3869 \\
\hline Kogi & 95 & 374 & 469 & 79 & 154 & 233 & 2085 & 3489 \\
\hline Kwara & 19 & 200 & 219 & 13 & 73 & 85 & 759 & 1368 \\
\hline Lagos & 0 & 0 & 0 & 33 & 0 & 33 & 286 & 352 \\
\hline Nasarawa & 22 & 110 & 132 & 29 & 90 & 119 & 937 & 1439 \\
\hline Niger & 179 & 184 & 363 & 129 & 134 & 263 & 2272 & 3524 \\
\hline Ogun & 0 & 0 & 0 & 154 & 73 & 226 & 1925 & 2378 \\
\hline Ondo & 20 & 185 & 205 & 54 & 153 & 206 & 1869 & 2692 \\
\hline Osun & 0 & 146 & 146 & 0 & 140 & 140 & 1200 & 1772 \\
\hline Oyo & 2 & 89 & 91 & 6 & 251 & 258 & 2386 & 3083 \\
\hline Plateau & 12 & 347 & 359 & 25 & 299 & 324 & 2926 & 4292 \\
\hline Rivers & 322 & 0 & 322 & 309 & 0 & 309 & 2956 & 4218 \\
\hline Sokoto & 246 & 539 & 785 & 150 & 45 & 195 & 1580 & 3540 \\
\hline Taraba & 15 & 430 & 445 & 33 & 238 & 270 & 2470 & 3901 \\
\hline Yobe & 183 & 99 & 282 & 183 & 20 & 203 & 1808 & 2778 \\
\hline Zamfara & 39 & 337 & 376 & 64 & 194 & 258 & 2408 & 3676 \\
\hline FCT Abuja & 25 & 1397 & 1422 & 10 & 74 & 84 & 804 & 3816 \\
\hline Total & 3857 & 10,790 & 14,647 & 3736 & 5369 & 9105 & 82,538 & 130,042 \\
\hline
\end{tabular}

\section{References}

1. UN-Water. Post-2015 Global Goal For Water; United Nations: Washignton, DC, USA, 2014; Volume 37.

2. The Economist Intelligence Unit. The Critical Role of Infrastructure for the Sustainable Development Goals; The Economist Intelligence Unit: London, UK, 2019.

3. Sachs, J.; Schmidt-Traub, G.; Kroll, C.; Lafortune, G.; Fuller, G.; Woelm, F. The Sustainable Development Goals and COVID-19. Sustainable Development Report 2020; Cambridge University Press: Cambridge, UK, 2020.

4. Ait-Kadi, M. Water for Development and Development for Water: Realizing the Sustainable Development Goals (SDGs) Vision. Aquat. Procedia 2016, 6, 106-110. [CrossRef]

5. $\quad$ UN-Water. Sustainable Development Goal 6 Synthesis Report on Water and Sanitation 2018 Sustainable Development Goal 6 Synthesis Report on Water and Sanitation; United Nations: New York, NY, USA, 2018.

6. United Nation Development Program. United Nations Development Goals. Dev. Goals 2015, 53, 21. 
7. UNESCO. Valuing Water-The United Nations World Water Development Report 2021; United Nations Educational, Scientific and Cultural Organization: Paris, France, 2021.

8. Grigg, N.S. Global water infrastructure: State of the art review. Int. J. Water Resour. Dev. 2019, 35, 181-205. [CrossRef]

9. Arimah, B. Infrastructure as a Catalyst for the Prosperity of African Cities. Procedia Eng. 2017, 198, 245-266. [CrossRef]

10. Mugagga, F.; Nabaasa, B.B. The centrality of water resources to the realization of Sustainable Development Goals (SDG). A review of potentials and constraints on the African continent. Int. Soil Water Conserv. Res. 2016. [CrossRef]

11. World Water Council. Water Infrastructure and Investment; World Water Council: Marseille, France, 2016.

12. Furlong, K. STS beyond the "modern infrastructure ideal": Extending theory by engaging with infrastructure challenges in the South. Technol. Soc. 2014, 38, 139-147. [CrossRef]

13. Eberhard, R. Access to Water and Sanitation in Sub-Saharan Africa: Part I-Synthesis Report; Deutsche Gesellschaft für Internationale Zusammenarbeit (GIZ) GmbH: Berlin, Germany, 2019; Volume 1.

14. Oyebande, L. Water problems in Africa-how can the sciences help? Hydrol. Sci. J. 2001, 46, 947-962. [CrossRef]

15. Okeke, I.C.; Oyebande, L. Water Resources Challenges in Nigeria: Pathways to Water Security and Sustainability; IAHS: Lagos, Nigeria, 2009; pp. 113-116.

16. Wagner, E.G.; Lanoix, J.N. Water Supply for Rural Areas and Small Communities; World Health Organisation: Geneva, Switzerland, 1959; Volume 42.

17. The World Bank. Nigeria-Second Multi-State Agricultural Development Project; The World Bank: Washington, DC, USA, 1995.

18. African Union. Progress on Implementing Water and Sanitation Goals in Africa: The 2011 Country Performance Report; The African Union Commission: Addis Ababa, Ethiopia, 2013; Volume 1.

19. WHO; UNICEF Joint Monitoring Programme. Progress on Drinking Water, Sanitation and Hygiene: 2017 Update and SDG Baselines; World Health Organization: Geneva, Switzerland, 2017. [CrossRef]

20. National Population Commission (NPC); ICF. Nigeria Demographic and Health Survey 2018; National Population Commission: Abuja, Nigeria; Rockville, MD, USA, 2019.

21. WHO. National Systems to Support Drinking-Water, Sanitation and Hygiene: Global Status Report 2019; World Health Organization: Geneva, Switzerland, 2020.

22. United Nations. World Urbanization Prospects-Population Division-United Nations 2019. Available online: https:// population.un.org/wup/Country-Profiles/ (accessed on 16 May 2019).

23. Federal Ministry of Water Resources. National Water Resources Masterplan 2013; Japan International Cooperation Agency (JICA): Abuja, Nigeria, 2014; Volume 4.

24. Federal Ministry of Water Resources. Transforming Irrigation Management in Nigeria (TRIMING) Project Environmental and Social Impact Assessment Final Report; Federal Ministry of Water Resources: Abuja, Nigeria, 2017.

25. Ojewale, C. The Private Sector is Key to Nigeria's \$22.5 Billion Food Import Bill. Business Day 2017:1. Available online: https: / / www.businessdayonline.com/private-sector-key-nigerias-22-5-billion-food-import-bill/ (accessed on 29 November 2017).

26. ICOLD. Definition of a Large Dam. 2011. Available online: https://www.icold-cigb.org/GB/dams/definition_of_a_large_dam. asp (accessed on 26 December 2019).

27. Federal Ministry of Water Resources. National Water Resources Policy; Federal Government of Nigeria: Abuja, Nigeria, 2016.

28. The World Bank. Nigeria I Data. Databank. 2019. Available online: https:/ / data.worldbank.org/country/nigeria (accessed on 28 December 2019).

29. Adedeji, A.A.; Ako, R.T. Towards achieving the United Nations' Millennium Development Goals: The imperative of reforming water pollution control and waste management laws in Nigeria. Desalination 2009, 248, 642-649. [CrossRef]

30. Adams, W.M. River basin planning in Nigeria. Appl. Geogr. 1985, 5, 297-308. [CrossRef]

31. Adeoti, O. Development of River Basin Organizations in Nigeria. Res. J. Soil Water Manag. 2011, 1, 91-100. [CrossRef]

32. Akpabio, E.M.; Ansa, I.E. Water for Cities in Nigeria: The Governance Dimension. Mediterr. J. Soc. Sci. 2013, 4, 297-310. [CrossRef]

33. FRN. Constitution of the Federal Republic of Nigeria. Constitution 1999:96. Available online: http://www.nigeria-law.org/ ConstitutionOfTheFederalRepublicOfNigeria.htm (accessed on 23 November 2018).

34. International Environmental Law Research Centre. Nigeria: Water Resources Decree. 1993, pp. 1-10. Available online: http:/ / www.ielrc.org/content/e9302.pdf (accessed on 28 November 2019). [CrossRef]

35. Ojiako, G.U. Nigerian Water Resources and Their Management. Water Int. 1985, 10, 64-72. [CrossRef]

36. Federal Ministry of Water Resources. National Water Policy; Federal Government of Nigeria: Abuja, Nigeria, 2004. [CrossRef]

37. Federal Ministry of Water Resources; JICA. Supporting Report 6-8: Water Resources Management Plan; Japan International Cooperation Agency (JICA): Abuja, Nigeria, 2014; Volume 5.

38. Familugba, O.J.; Ojo, O.O. Nigeria-Cameroon Border Relations: An Analysis of the Conflict and Cooperation (1970-2004). Int. J. Humanit. Soc. Sci. 2013, 3, 181-190.

39. United Nations. Human Development Index and Its Components. 2019. Available online: http://hdr.undp.org/en/composite/ HDI (accessed on 24 May 2019).

40. International Monetary Fund. World Economic Outlook: Global Manufacturing Downturn, Rising Trade Barriers; International Monetary Fund: Washington, DC, USA, 2019. 
41. African Union. Regional Economic Communities (RECs). 2019. Available online: https://au.int/en/organs/recs (accessed on 3 March 2019).

42. Johnson, S. The History of The Yorubas: From the Earliest Times to the Beginning of the British Protectorate; Lowe and Brydone: London, UK, 1921.

43. Barth, H. Travels and Discoveries in North and Central Africa: Being a Journal of an Expedition Undertaken under the Auspices of H.B.M.'s Government, in the Years 1849-1855; Drallop: New York, NY, USA, 1853; Volume 1.

44. Barth, H. Travels and Discoveries in North and Central Africa: Being a Journal of an Expedition Undertaken under the Auspices of H.B.M.'s Government, in the Years 1849-1855; D. Appleton and Co.: New York, NY, USA, 1857; Volume 3.

45. FAO. Land Use. FAOSTAT, 2019. Available online: http://www.fao.org/faostat/en/\#data/RL (accessed on 10 March 2020).

46. van der Wijngaart, R.; Helming, J.; Jacobs, C.; Andrés Garzón Delvaux, P.; Hoek, S.; Gomez Paloma, S. Irrigation and Irrigated Agriculture Potential in the Sahel: The Case of the Niger River Basin; Publications Office of the European Union: Paloma, Spain, 2019. [CrossRef]

47. WHO. WHOICountry Profiles of Environmental Burden of Disease. WHO, 2019. Available online: https://www.who.int/ quantifying_ehimpacts/national/countryprofile/en/ (accessed on 14 November 2019).

48. United Nations, Department of Economic and Social Affairs PD. World Population Prospects: Volume I: Comprehensive Tables; United Nations: New York, NY, USA, 2019.

49. McBow, D.W.; Ukeje, L.O. Desert Blooms; Government of Nigeria: Lagos, Nigeria, 1959.

50. Barth, H. Travels and Discoveries in North and Central Africa:Being a Journal of an Expedition Undertaken under the Auspices of H.B.M.'s Government, in the Years 1849-1855; Longman, Brown, Green and Roberts: London, UK, 1858; Volume 4.

51. Barth, H. Travels and Discoveries in North and Central Africa:Being a Journal of an Expedition Undertaken under the Auspices of H.B.M.'s Government, in the Years 1849-1855; Harper and Brothers: New York, NY, USA, 1857; Volume 2.

52. Bascom, W. Urbanization Among the Yoruba. Am. J. Sociol. 1955, 60, 446-454. [CrossRef]

53. Hinderer, A. Sevennteen Years in the Yoruba Country: Memorials of Anna Hinderer; The Religious Tract Society: London, UK, 1877.

54. IBRD-IDA. Economic Growth of Nigeria: Problems and Prospects; The World Bank: Washington, DC, USA, 1965 ; Volume 3.

55. Hazell, R. British hydrogeologists in West Africa-An historical evaluation of their role and contribution. Geol. Soc. Lond. Spec. Publ. 2004, 225, 229-237. [CrossRef]

56. Olukoju, A. Water supply in the nineteenth and twentieth centuries. In Infrastructure Development and Urban Facilities In Lagos, 1861-2000; IFRA-Nigeria: Ibadan, Nigeria, 2003; pp. 47-79. [CrossRef]

57. Okigbo, P.N.C. National Development Planning in Nigeria 1900-92; Currey: London, UK, 1989.

58. The World Bank. Appraisal of Funtua Agricultural Development Project, Nigeria; The World Bank: Abuja, Nigeria, $1974 ;$ Volume 1.

59. IEG. Agricultural Development Projects in Nigeria. 2012. Available online: http://lnweb90.worldbank.org/oed/oeddoclib.nsf/ DocUNIDViewForJavaSearch/FE7BA13642E3E0D7852567F5005D85CF (accessed on 17 August 2018).

60. JICA; Federal Ministry of Water Resources and Rural Development. The Study on the National Water Resources Masterplan (NWRMP) Summary and Main Text; Japan International Cooperation Agency (JICA): Abuja, Nigeria, 1995; Volume 1.

61. The World Bank. Japanese Grant Agreement (National Water Rehabilitation Fund Project) between Federal Republic of Nigeria and International Bank for Reconstruction and Development; The World Bank: Washington DC, USA, 1990. [CrossRef]

62. JICA; Federal Ministry of Water Resources and Rural Development. The Study of the 1995 National Water Resources Masterplan Dam Inventry; Japan International Cooperation Agency (JICA): Abuja, Nigeria; Federal Government of Nigeria: Abuja, Nigeria, 1995; Volume 4.

63. Federal Ministry of Water Resources. Compendium of Dams: Their Briefs, Statistics and Purposes; Federal Government of Nigeria: Abuja, Nigeria, 2007.

64. UNGA. Proclamation of the International Drinking Water Supply and Sanitation Decade; United Nations: New York, NY, USA, 1980; Volume 1.

65. Abubakar, I.U.; Yamusa, M.A. Recurrence of Drought in Nigeria: Causes, Effects and Mitigation. Int. J. Agric. Food Sci. Technol. 2013, 4, 169-180.

66. Mabogunje, A.L. Urbanisation in Nigeria, 1st ed.; University of London: London, UK, 1968.

67. Collier, P.; Cust, J. Investing in Africa's Infrastructure: Financing and Policy Options. Annu. Rev. Resour. Econ. $2015,7,473-493$. [CrossRef]

68. Utietiang, B. Historicizing Development: Nigeria's 1945 Colonial Plan. J. Pan. Afr. Stud. 2015, 8, 5-25.

69. Papaioannou, K.J.; Dalrymple-Smith, A.E. Political instability and discontinuity in Nigeria: The pre-colonial past and public goods provision under colonial and post-colonial political orders. Econ. Peace Secur. J. 2015, 10, 40-53. [CrossRef]

70. Ertsen, M.W. Controlling the farmer: Colonial and post- colonial irrigation interventions in Africa. J. Transdiscipl. Res. S. Afr. 2008, 4, 209-236. [CrossRef]

71. Swyngedouw, E. Technonatural revolutions: The scalar politics of Franco's hydro-social dream for Spain, 1939-1975. Trans. Inst. Br. Geogr. 2007, 32, 9-28. [CrossRef]

72. Verhoeven, H. Water, Civilisation and Power in Sudan: The Political Economy of Military-Islamist State Building; Cambridge University Press: New York, UK, 2015. [CrossRef]

73. Hoffmann, L.K. Who Speaks for the North? Politics and Influence in Northern Nigeria; Chatham House: London, UK, 2014.

74. UNDP. Human Development Report 2018: Achieving Human Development in North East Nigeria; UNDP: Abuja, Nigeria, 2018. 
75. Shiru, M.S.; Shahid, S.; Dewan, A.; Chung, E.S.; Alias, N.; Ahmed, K.; Hassan, Q.K. Projection of meteorological droughts in Nigeria during growing seasons under climate change scenarios. Sci. Rep. 2020, 10, 10107. [CrossRef] [PubMed]

76. Anyadike, R.N.C. Seasonal and annual rainfall variations over Nigeria. Int. J. Climatol. 1993, 13, 567-580. [CrossRef]

77. Amanambu, A.C.; Li, L.; Egbinola, C.N.; Obarein, O.A.; Mupenzi, C.; Chen, D. Spatio-temporal variation in rainfall-runoff erosivity due to climate change in the Lower Niger Basin, West Africa. Catena 2019, 172, 324-334. [CrossRef]

78. Adams, W.M. Development's deaf ear: Downstream users and water releases from the Bakolori Dam, Nigeria. World Dev. 1993, 21, 1405-1416. [CrossRef]

79. Federal Republic of Nigeria. Guidelines for the Third National Development Plan: 1975-1980; The Central Planning Office of the Federal Ministry of Economic Development and Reconstruction: Lagos, Nigeria, 1974.

80. Nigeria Legislative Council. A Ten-Year Plan of Development and Welfare for Nigeria; Government Printer: Lagos, Nigeria, 1946.

81. Filani, M.O. Transport and rural development in Nigeria. J. Transp. Geogr. 1993, 1, 248-254. [CrossRef]

82. Mabogunje, A.L. New initiatives in urban planning and management in Nigeria. Habitat. Int. 1992, 16, 73-88. [CrossRef]

83. Onokerhoraye, A.G. The Urban System and National Integration in Nigeria. J. Black Stud. 1978, 9, 169-180. [CrossRef]

84. Andres, L.; Chellaraj, G.; Gupta BDas Grabinsky, J.; Joseph, G. Why Are So Many Water Points in Nigeria Non-Functional? An Empirical Analysis of Contributing Factors; The World Bank: Washignton, DC, USA, 2018; Volume 8388. [CrossRef]

85. Abubakar, I.R. Access to sanitation facilities among nigerian households: Determinants and sustainability implications. Sustainability 2017, 9, 547. [CrossRef]

86. Macheve, B.; Danilenko, A.; Abdullah, R.; Bove, A.; Moffitt, L.J. State Water Agencies in Nigeria: A Performance Assessment; World Bank Group: Washington, DC, USA, 2015. [CrossRef]

87. Andres, L.; Chellaraj, G.; Das Gupta, B.; Grabinsky, J.; Joseph, G. An Evaluation of the Contributing Factors of Water Scheme Failures in Nigeria; The World Bank: Washignton, DC, USA, 2018. [CrossRef]

88. Franks, T.R.; Cleaver, F.D. Water governance and poverty: A framework for analysis. Prog. Dev. Stud. 2007, 7, 291-306. [CrossRef]

89. Nwosu, N.I. The State and Rural Development in Nigeria. Ufahamu. J. Afr. Stud. 1990, 18, 52-65.

90. Lewis, A.O. Nigeria's Third National Development Plan, 1975-1980: An appraisal of objectives and policy frame. Dev. Econ. 1977, 15, 60-79. [CrossRef]

91. Waziri, I.M. Political Economy of Development: Discussion and Analysis of the Nigerian Federal Government Development Policies on Agriculture over the Period: 1975-1985; ETD Collection for AUC Robert W. Woodruff Library; AUC Robert W. Woodruff Library: Atlanta, GA, USA, 1989.

92. The World Bank. First Multistate Water Supply Project; The World Bank: Washignton, DC, USA, 1992; unpublished.

93. Watts, M. Silent Violence: Food, Famine, and Peasantry in Northern Nigeria, 1st ed.; University of California Press: Berkeley, CA, USA, 1983.

94. Federation of Nigeria. National Development Plan 1962-1968; The Federal Ministry of Economic Development: Lagos, Nigeria, 1962.

95. Edwardes HSW. Lake Formation and Desiccation in Africa. Geogr. J. 1919, 53, 206. [CrossRef]

96. Bjornlund, V.; Bjornlund, H.; van Rooyen, A.F. Exploring the factors causing the poor performance of most irrigation schemes in post-independence sub-Saharan Africa. Int. J. Water Resour. Dev. 2020, 36, S54-S101. [CrossRef]

97. Lugard, F.J.D. The Dual Mandate in British Tropical Africa Baron, 1858-1945; William Blackwood and Sons: Edinburgh/London, UK, 1922.

98. Federal Republic of Nigeria. Third National Development Plan 1975-80; Government Printer: Lagos, Nigeria, 1975.

99. Gowon, Y. Nigeria on the Threshold of Socio-Economic Revolution: Message to the Nation on the Occasion of the 13th Independence Anniversary Celebration on the 1st October 1973; Federal Government Press: Lagos, Nigeria, 1973.

100. The World Bank. First Multistate Agricultural Development Project, Second Multistate Agricultural Development Project, and Third Multistate Agricultural Development Project; The World Bank: Washington, DC, USA, 1998.

101. OYSADEP. OYSADEP Documents; Oyo State Government: Ibadan, Nigeria, 1989.

102. GWP-N. The Post-2015 Development Agenda Nigeria Stakeholder Perspectives on a Water Goal and Its Implementation; Global Water Partnership (GWP): Stockholm, Sweden, 2014.

103. Danert, K.; Adekile, D.; Canuto, J.G. Striving for Borehole Drilling Professionalism in Africa: A Review of a 16-Year Initiative through the Rural Water Supply Network from 2004 to 2020. Water 2020, 12, 3305. [CrossRef]

104. Moe, C.L.; Rheingans, R.D. Global challenges in water, sanitation and health. J. Water Health 2006, 4, 41-58. [CrossRef]

105. Tetra Tech. Sector Assessment Summary: Nigeria USAID WASH Sector Status and Trends in Water and Development Strategy Priority Countries; USAID: Burlington, VT, USA, 2015.

106. Lane, J. Barriers and Opportunities for Sanitation and Water for All, as Envisaged by the New Delhi Statement. IDS Bull. 2012, 43, 13-20. [CrossRef]

107. Adetola, B. FG to Commence Construction of 370 New Dams. Trib Online. 2016. Available online: https://tribuneonlineng.com/ 16633 / (accessed on 5 June 2019).

108. Oyeniyi, S.O.; Oloyede, J.O. A Comparative Analysis of Safe Water and Sanitation in Selected Urban and Rural Areas of Osun State, Nigeria. Donnish J. Res. Environ. Stud. 2016, 3, 8-16.

109. Adamu, S.H. Immediate and Long Term Strategies for the Water Sector (2016-2030). Available online: https:/ / theeagleonline. com.ng/tag/immediate-and-long-term-strategies-for-water-sector-2016-2030/2016 (accessed on 15 April 2017). 
110. Obeta, M.C. Rural water supply in Nigeria: Policy gaps and future directions. Water Policy 2018, 20, 597-616. [CrossRef]

111. Nduduba, O.I. Inventory Of Existing Rural Water Supply Sources Using Model Nigerian Communities Vis a Vis Household Access to Improved Water. IOSR J. Mech. Civ. Eng. 2014, 11, 16-23.

112. Akanmu, J.O.; Remi-John, O.; Ekpo, I.E. Overview of Dam Development in Nigeria. Geotech. Geol. Eng. 2011, $29,953-960$. [CrossRef]

113. Nilsson, D.; Nyanchaga, E.R. Pipes and politics: A century of change and continuity in Kenyan urban water supply. J. Mod. Afr. Stud. 2008, 46, 133-158. [CrossRef]

114. Furlong, K. Small technologies, big change: Rethinking infrastructure through sts and geography. Prog. Hum. Geogr. 2011, 35, 460-482. [CrossRef]

115. Moss, T. Socio-technical Change and the Politics of Urban Infrastructure: Managing Energy in Berlin between Dictatorship and Democracy. Urban Stud. 2014, 51, 1432-1448. [CrossRef]

116. Abdullaev, I.; Mollinga, P.P. The Socio-Technical Aspects of Water Management: Emerging Trends at Grass Roots Level in Uzbekistan. Water 2010. [CrossRef]

117. WHO; UNICEF. Progress on Household Drinking Water, Sanitation and Hygiene 2000-2017; World Health Organization: New York, NY, USA, 2019.

118. Komakech, H.C.; Kwezi, L.; Ali, M. Why prepaid technologies are not a panacea for inclusive and sustainable rural water services in Tanzania? Water Policy 2020, 22, 925-942. [CrossRef]

119. CIA. Country Comparison to the World: Waterways. CIA Factb. 2011. Available online: https://www.cia.gov/LIBRARY/ publications / the-world-factbook/ fields / print_2093.html (accessed on 2 June 2019).

120. Cosgrove, W.J.; Loucks, D.P. Water management: Current and future challenges and research directions. Water Resour. Res. 2015, 51, 4823-4839. [CrossRef]

121. MacDonald, C.M. Exploration of the Benue and Its Northern Tributary the Kebbi. Proc. R. Geogr. Soc. Mon. Rec. Geogr. 1891, 13, 449. [CrossRef]

122. WTTC. Country Reports: Nigeria; WTTC: London, UK, 2019.

123. Bankole, A. The Nigerian Tourism Sector: Economic Contribution, Constraints, and Opportunities. J. Hosp. Financ. Manag. 2002, 10, 69-89. [CrossRef]

124. Christie, I.; Fernandes, E.; Messerli, H.; Twining-Ward, L. Tourism in Africa: Harnessing Tourism for Growth and Improved Livelihoods; World Bank: Washington, DC, USA, 2014. [CrossRef]

125. World Bank. 20 Reasons Sustainable Tourism Counts for Development Knowledge; The World Bank: Washington, DC, USA, 2017.

126. James, E.E.; Udo Essien, A. Infrastructure and Sustainable Tourism Development in Nigeria. J. Humanit. Soc. Sci. 2019, 24, 72-80. [CrossRef]

127. Federal Ministry of Water Resources. Supporting Report 5: Water Resources Sub-Sector Development Plan; Japan International Cooperation Agency (JICA): Abuja, Nigeria, 2014; Volume 5.

128. WHO; UNICEF. JMP Methodology 2017 Update E Sdg Baselines; UNICEF: Washington, DA, USA, 2018.

129. Ajisegiri, B. Partnership for Expanded Water Supply, Sanitation and Hygiene (PEWASH): Programme Strategy (2016-2030); Federal Government of Nigeria: Abuja, Nigeria, 2016; pp. 1-49.

130. Moran, E.F.; Lopez, M.C.; Moore, N.; Müller, N.; Hyndman, D.W. Sustainable hydropower in the 21st century. Proc. Natl. Acad. Sci. USA 2018, 115, 11891-11898. [CrossRef]

131. Muller, M.; Biswas, A.; Martin-Hurtado, R.; Tortajada, C. Built infrastructure is essential. Science 2015, 349, 585-586. [CrossRef] [PubMed]

132. Alhassan, B.; Saddik, A.I.; Abaka, N.T.J.U.; Gumel, A.H. Small Earth Dams in Nigeria: Prospects and Challenges. J. Energy Technol. Policy 2019, 9, 14-17. [CrossRef]

133. PIDA. PIDA Projects Dashboard. Virtual PIDA information Central 2019:1. Available online: http://www.au-pida.org/pidaprojects / (accessed on 3 March 2019).

134. Mgbolu, C.C.; Obiadi, I.I.; Obiadi, C.M.; Okolo, C.M.; Irumhe, P.E. Integrated groundwater potentials studies, aquifer hydraulic characterisation and vulnerability investigations of parts of Ndokwa, Niger Delta Basin, Nigeria. Solid Earth Sci. 2019, 4, 102-112. [CrossRef]

135. Werth, S.; White, D.; Bliss, D.W. GRACE Detected Rise of Groundwater in the Sahelian Niger River Basin. J. Geophys Res. Solid Earth 2017, 122, 10459-10477. [CrossRef]

136. Daniell, K.A. Practical responses to water and climate policy implementation challenges. Australas J. Water Resour. 2013, 17, 111-125. [CrossRef]

137. International Hydropower Association. 2018 Hydropower Status Report: Sector Trends and Insights; International Hydropower Association Limited: London, UK, 2018. 